\title{
Distribution of Convective Intensities in West Africa Using Reflectivity and Ice Scattering Characteristics from TRMM Precipitation Features
}

\author{
Richard Ayodeji Balogun ${ }^{1 *}$, Zechariah Debo Adeyewa ${ }^{1,2}$ \\ ${ }^{1}$ Department of Meteorology, Federal University of Technology Akure (FUTA), Akure, Nigeria \\ ${ }^{2}$ Vice Chancelor's Office, Redeemer's University (RUN), Ede, Nigeria \\ Email: ^rabalogun@futa.edu.ng,vc@run.edu.ng
}

How to cite this paper: Balogun, R.A. and Adeyewa, Z.D. (2017) Distribution of Convective Intensities in West Africa Using Reflectivity and Ice Scattering Characteristics from TRMM Precipitation Features. Atmospheric and Climate Sciences, 7, 127-150. http://dx.doi.org/10.4236/acs.2017.71010

Received: June 3, 2016

Accepted: January 21, 2017

Published: January 24, 2017

Copyright $\odot 2017$ by authors and Scientific Research Publishing Inc. This work is licensed under the Creative Commons Attribution International License (CC BY 4.0).

http://creativecommons.org/licenses/by/4.0/ (c) (i) Open Access

\section{Abstract}

An evaluation of Radar Precipitation Feature (RPF) characteristics and distribution of convective intensity is performed across 12 regions in West Africa. Results presented in this study have shown that these characteristics over West Africa revealed interesting results which were not observed on a larger spatial scale. The ice scattering characteristics and heights attained by the $15,20,30$, and $40 \mathrm{dBZ}$ echoes show patterns that agree with the season and movement of the Inter-Tropical Discontinuity (ITD). Some locations in the Western-coast rainforest, Nigeria/Cameroon rainforest and South Sudan savannah had strong potential for convective intensity during MAM, JJA, and SON as shown by their 37-GHz and $85-\mathrm{GHz}$ PCT which fell below $250 \mathrm{~K}$ and $225 \mathrm{~K}$ respectively while the maximum height attained by their 20 $\mathrm{dBZ}, 30 \mathrm{dBZ}$ and $40 \mathrm{dBZ}$ are well above the freezing level in those locations. One result revealed a location on the eastern part of south-central Sahel (SC Sahel) where the maximum height attained by the $30 \mathrm{dBZ}$ reflectivity is above $12 \mathrm{~km}$ and the maximum height attained by the $40 \mathrm{dBZ}$ reflectivity is above $10 \mathrm{~km}$ during SON. The $37-\mathrm{GHz}$ and $85-\mathrm{GHz}$ PCT for this particular location are below $215 \mathrm{~K}$ and $150 \mathrm{~K}$ respectively indicating a very strong potential for intense convection and hence destructive storms. The distribution of convective intensity, considering only the 85$\mathrm{GHz}$ PCT ice scattering signature, revealed that the percentage of convective intensity increases, especially in the rainforest and savannah, as the ITD shifts northwards during MAM, JJA and during its retreat in SON.

\section{Keywords}

Precipitation Feature (PF), Convective Intensity, Inter-Tropical Discontinuity, Radar Echoes, Polarization Corrected Temperature (PCT) 


\section{Introduction}

The Tropical Rainfall Measuring Mission (TRMM) satellite has collected detailed measurements of rainstorms in the Tropics and subtropics since its launch in late 1997. The instrument suite provides simultaneous measurement of many quantities related to precipitation, for example, radar reflectivity, passive microwave brightness temperature, infrared cloud-top temperature, lightning flash rate and location. This combination allows detailed characterization of individual precipitation features. The precipitation features are basically contiguous areas of precipitation, with no upper limit imposed on their size. A single precipitation feature can be smaller than $100 \mathrm{~km}^{2}$ or larger than $10,000 \mathrm{~km}^{2}$, containing many individual convective cells. The characteristics of precipitation features are presented here, representing the first eleven (11) years of TRMM observations over twelve (12) selected regions in West Africa. The purpose is to provide a subtropical context for individual cases and for regional, seasonal, or other regime-dependent studies. Furthermore, the study seeks to improve the understanding of individual measurable characteristics by exploiting simultaneous measurements of other characteristics derived from radar precipitation features in the TRMM precipitation radar.

The University of Utah Precipitation Feature (PF) database, also operating at Texas A \& M University Corpus Christi (TAMUCC), is a large and comprehensive database which enables qualitative and quantitative analysis of relationships between these characteristics, [1] [2] [3], and/or much smaller sets of storms from particular regions [4] [5] [6]. Many of the relationships presented here are consistent with those reported in previous studies, but the size of this database and the unique combination of radar, radiometer, and lightning sensor allow some analyses that would otherwise be less comprehensive or even impossible. Emphasis is placed on the most vigorous and/or largest features, as these have the greatest impact on the hydrologic cycle, latent heating, atmospheric composition, and hazards to humans.

Dual polarized (vertical and horizontal) passive microwave observations provide two major pieces of information about precipitation: 1) an emission signal and 2) a scattering signal. The emission signal comes from attenuation by liquid water below the freezing level. This attenuation is related to the surface rain rate via assumptions about the partitioning of cloud and rain water, and the vertical profile of rain water. The scattering signal is observed when the brightness temperature is depressed [7] [8] [9] [10] by scattering due to optical depths of precipitation-sized ice particles above the freezing level within the instrument footprint ( $5-7 \mathrm{~km}$ for TMI, with $14 \mathrm{~km}$ between successive scans), which is also related to clouds and precipitation. The magnitude of this ice scattering signature depends on the optical depth, which in turn depends on factors such as the wavelength, the vertical distribution of hydrometeors, and the phase, density, size, and concentration of these hydrometeors.

Because of its shorter wavelength, $85-\mathrm{GHz}$ (3.5- $\mathrm{mm}$ wavelength) is more sensitive to smaller ice particles than the $37-\mathrm{GHz}$ (8.1-mm wavelength), [11]. Small precipitation-sized ice particles scatter less of the upwelling radiation at longer wavelength. Compared to $85-\mathrm{GHz}$ PCT, 37-GHz PCT is more sensitive to large ice particles in the precipitating systems than to small ice particles. Thus, low values of minimum PCT at 
$85-\mathrm{GHz}$ tend to indicate a large ice water path, while low values at $37-\mathrm{GHz}$ tend to indicate that the feature contains larger ice particles, [12]. Particles with diameters several hundred microns or larger are in the Mie regime at $85-\mathrm{GHz}$, but only $\mathrm{O}(\mathrm{mm})$ size particles are in the Mie regime at $37-\mathrm{GHz}$. The magnitude of $85-\mathrm{GHz}$ scattering, as indicated by the PCT, has been used to characterize the vigor and spatial extent of convective systems (e.g., [5] [13] [14] [15]). The 85- and 37-GHz channels can only detect the scattering signature from ice particles with diameters greater than about $0.1 \mathrm{~mm}$. The TMI usually cannot observe signals from anvil clouds because ice particles in anvils are usually smaller than $0.1 \mathrm{~mm}$. However, the VIRS $10.8-\mathrm{mm}$ channel is sensitive to the cloud-top temperature.

The West African major climatic regions include the Rainforest, Savannah, and Sahel. These climatic regions are further divided into smaller (micro) sub-regions as shown in Figure 1. The Rainforest (tropical wet) climate lies below the northern savanna region. It is a wet and warm climate with high, all-year rainfall. The average annual rainfall can be as much as $1800 \mathrm{~mm}$, and the climate resembles the equatorial climate. However, although rainfall is more concentrated in one season, no month is rainless. This zone has towering evergreen trees, oil palms, and numerous species of tropical hardwood trees under which one generally finds a dense surface covering of shrubs, ferns, and mosses. The savanna climate zone is characterized by a wet season during the summer months and a dry season during the winter months. Rainfall ranges between 100 and $400 \mathrm{~mm} \cdot \mathrm{yr}^{-1}$. The region could vary in vegetation type from opencanopied forests with a grassy understory to real savanna regions for which grasses are dominant. The Sahel zone serves as a transition zone between the arid Sahara in the north and the wetter savanna region in the south. The Sahel zone has a steppe climate with low precipitation. Annual rainfall generally averages between 100 and $200 \mathrm{~mm}$ and

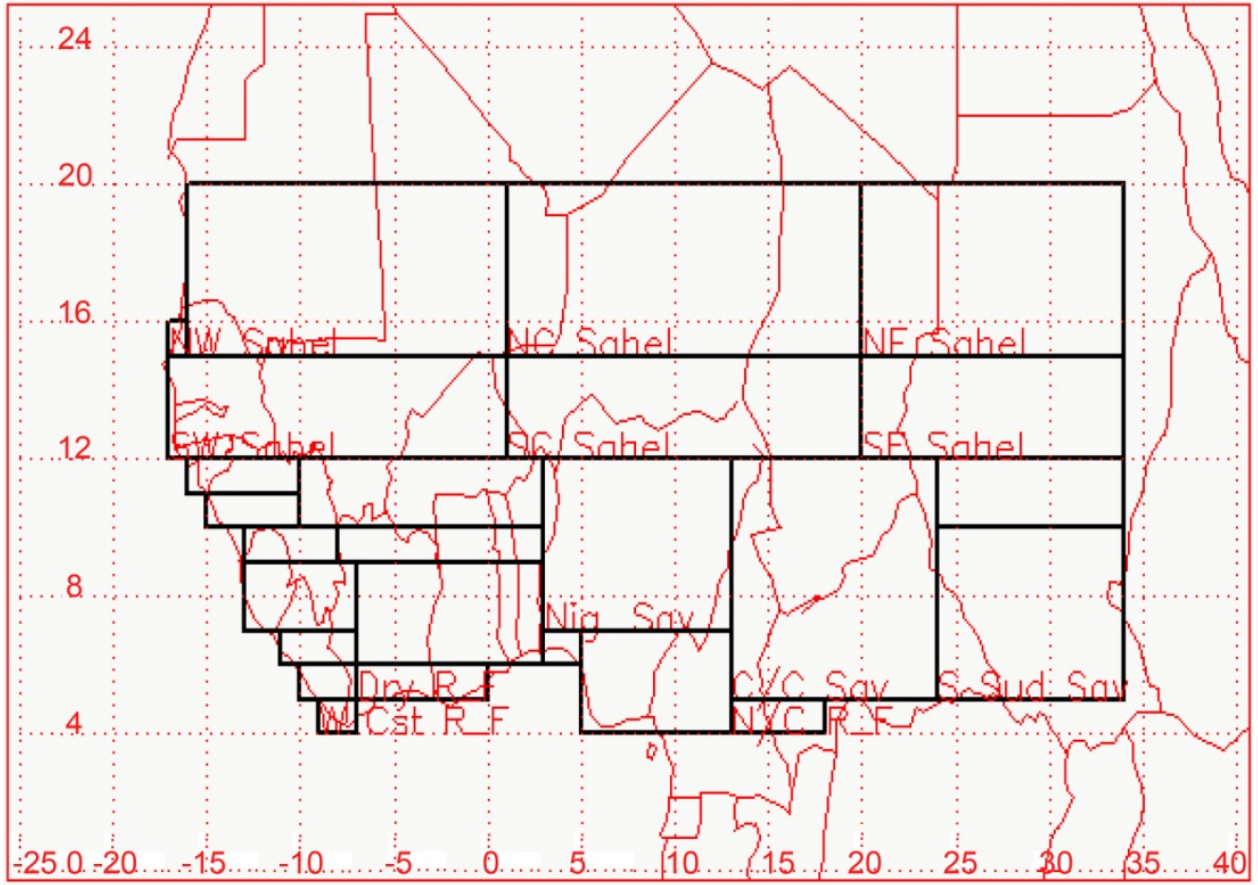

Figure 1. Study area showing the twelve (12) selected climate zones. 
is mostly confined to within June through September. The vegetation is relatively sparse, and grasses and shrubs predominate.

This paper seeks to understand convective intensities in the West Africa sub-region and how these intensities are distributed across each zone under investigation.

Table 1 shows how each of these climate regions was partitioned based on their

Table 1. Sub_regions, number of boxes in a sub_region, and their respective longitudes and latitudes.

\begin{tabular}{|c|c|c|c|c|c|}
\hline SUB_REGIONS & $\begin{array}{c}\text { No of } \\
\text { SUB_BOXES }\end{array}$ & MIN_LAT & MAX_LAT & MIN_LON & MAX_LON \\
\hline \multirow[t]{3}{*}{ NW Sahel } & 2 & & & & \\
\hline & & 15.0 & 16.0 & -17.0 & -16.0 \\
\hline & & 15.0 & 20.0 & -16.0 & 1.0 \\
\hline \multirow[t]{2}{*}{ NC Sahel } & 1 & & & & \\
\hline & & 15.0 & 20.0 & 1.0 & 20.0 \\
\hline \multirow[t]{2}{*}{ NE Sahel } & 1 & & & & \\
\hline & & 15.0 & 20.0 & 20.0 & 34.0 \\
\hline \multirow[t]{2}{*}{ SW Sahel } & 1 & & & & \\
\hline & & 12.0 & 15.0 & -17.0 & 1.0 \\
\hline \multirow[t]{2}{*}{ SC Sahel } & 1 & & & & \\
\hline & & 12.0 & 15.0 & 1.0 & 20.0 \\
\hline \multirow[t]{3}{*}{ SE Sahel } & 2 & & & & \\
\hline & & 12.0 & 15.0 & 20.0 & 34.0 \\
\hline & & 10.0 & 12.0 & 24.0 & 34.0 \\
\hline \multirow[t]{8}{*}{ W Cst R_F } & 7 & & & & \\
\hline & & 4.0 & 5.0 & -9.0 & -7.0 \\
\hline & & 5.0 & 6.0 & -10.0 & -7.0 \\
\hline & & 6.0 & 7.0 & -11.0 & -7.0 \\
\hline & & 7.0 & 9.0 & -13.0 & -7.0 \\
\hline & & -9.0 & -10.0 & -13.0 & -8.0 \\
\hline & & 10.0 & 11.0 & -15.0 & -10.0 \\
\hline & & 11.0 & 12.0 & -16.0 & -10.0 \\
\hline \multirow[t]{5}{*}{ Dry R_F } & 4 & & & & \\
\hline & & 5.0 & 6.0 & -7.0 & 0.0 \\
\hline & & 6.0 & 9.0 & -7.0 & 3.0 \\
\hline & & 9.0 & 10.0 & -8.0 & 3.0 \\
\hline & & 10.0 & 12.0 & -10.0 & 3.0 \\
\hline \multirow[t]{2}{*}{ Nig. Sav } & 1 & & & & \\
\hline & & 7.0 & 12.0 & 3.0 & 13.0 \\
\hline \multirow[t]{2}{*}{ C/C Sav } & 1 & & & & \\
\hline & & 5.0 & 12.0 & 13.0 & 24.0 \\
\hline \multirow[t]{2}{*}{ S SudSav } & 1 & & & & \\
\hline & & 5.0 & 10.0 & 24.0 & 34.0 \\
\hline \multirow[t]{4}{*}{ N/C R_F } & 3 & & & & \\
\hline & & 4.0 & 5.0 & 13.0 & 18.0 \\
\hline & & 4.0 & 7.0 & 5.0 & 13.0 \\
\hline & & 6.0 & 7.0 & 3.0 & 5.0 \\
\hline
\end{tabular}


longitudes and latitudes. For example, Western Coast Rainforest (W Cst R_F) has seven boxes which spans from $4^{\circ} \mathrm{N}$ to $12^{\circ} \mathrm{N}$ along the west coastal areas of West Africa just below "SW Sahel".

\section{Data and Methodology}

An 11-yr (January 1998 through December 2008) radar precipitation feature database was developed by Liu and his colleagues in 2008. The database consists of simultaneous observations from the Precipitation Radar (PR), TRMM Microwave Imager (TMI), Visible and Infrared Sensor (VIRS) and Lightning Imaging Sensor (LIS) aboard the TRMM satellite. The precipitation features are basically contiguous areas of precipitation, with no upper limit imposed on their size. A single precipitation feature can be smaller than $100 \mathrm{~km}^{2}$ or larger than $10,000 \mathrm{~km}^{2}$, containing many individual convective cells. A single precipitation feature could easily span a few of the boxes marked in Figure 1. The minimum $37-\mathrm{GHz}$ and85-GHz PCTs is taken for the radar precipitation feature under investigation. The maximum height of a 15,20,30, or $40 \mathrm{dBZ}$ radar echo is also taken for the radar precipitation feature.

This study evaluates the TRMM Precipitation Feature (PF) level-3 data to analyze and generate Precipitation Characteristics over the West African Region, which includes the Rainforest, Savannah, and Sahel regions in West Africa. These climatic regions are further partitioned into smaller (micro) sub-regions from a general classification for the African continent, as shown in Figure 1. The analysed precipitation characteristics are grouped into the following categories:

1) Ice Scaterring Characteristics; and

2) Radar Reflectivity Characteristics.

[13] used a $250 \mathrm{~K} 85-\mathrm{GHz}$ PCT threshold as a proxy for moderate rainfall in defining Mesoscale Convective Systems (MCS). Although $250 \mathrm{~K}$ at $85-\mathrm{GHz}$ usually corresponds to a greater rain rate $\left(\sim 3 \mathrm{~mm} \cdot \mathrm{h}^{-1}\right)$ than $20 \mathrm{dBZ}$ reflectivity $\left(\sim 0.5 \mathrm{~mm} \cdot \mathrm{h}^{-1}\right)$, it is noteworthy and not surprising that so much of the area (land areas close to the ocean) experiencing rainfall (at least 20- $\mathrm{dB} Z$ radar reflectivity) has an $85-\mathrm{GHz}$ PCT between 182 $\mathrm{K}$ and $250 \mathrm{~K}$. [16] reasoned that storms containing higher $30 \mathrm{dBZ}$ heights likely contain more intense electric fields (and therefore more lightning), larger supercooled water and ice water contents; the second condition leading to lower $85-\mathrm{GHz}$ PCTs.

While we adopt the view that intensity can be defined by the properties of the convective updrafts in a storm, it is impossible to measure them around the world [17]. Therefore, we define proxies for convective intensity that can be measured by the TRMM satellite. Besides the lightning measurements from TRMM, the radar reflectivities and passive microwave brightness temperatures have been used as proxies for convective vigour. This is based on large graupel or hail lofted by strong updrafts being the cause of high-radar reflectivity values aloft and extremely low brightness temperatures.

Following [17] which was based on [18] and physical reasoning outlined in many other studies, proxies for convective intensity are defined as follows:

The higher the height attained by the $40-\mathrm{dBZ}$ level in a PF, the more intense the storm;

The lower the minimum brightness temperature attained in a $\mathrm{PF}$ at 37 and $85 \mathrm{GHz}$, 
the more intense the storm; and

The greater the lightning flash rate attained in a PF, the more intense the storm.

To remove the ambiguity between low brightness temperatures due to ice scattering and due to low surface emissivity, the TMI vertically and horizontally polarized brightness temperatures were combined at $37 \mathrm{GHz}$ and $85 \mathrm{GHz}$ yielding a Polarization Corrected Temperature (PCT). At $85 \mathrm{GHz},[10]$ developed the relationship:

$$
\mathrm{PCT}_{85 \mathrm{GHz}}=1.82 \mathrm{~T}_{\mathrm{B} 85 \mathrm{~V}}-0.82 \mathrm{~T}_{\mathrm{B} 85 \mathrm{H}}
$$

The one at $37 \mathrm{GHz}$ defined by [11] was utilized as follows:

$$
\mathrm{PCT}_{37 \mathrm{GHz}}=2.20 \mathrm{~T}_{\mathrm{B} 37 \mathrm{~V}}-1.20 \mathrm{~T}_{\mathrm{B} 37 \mathrm{H}}
$$

where $T_{B}$ is the brightness temperature, $V$ and $H$ in the subscripts are vertical and horizontal polarizations, respectively.

For many observational purposes, it is appropriate to think of $85-\mathrm{GHz}$ as simply an ice scattering channel (e.g., [5] [14]), in which precipitation sized ice reduces the observed brightness temperature by scattering the upwelling radiation [7] [8] [9] [10]. The $85-\mathrm{GHz}$ PCT depends on the scattering of upwelling radiation by the lofted precipitation-sized ice particles. This ice scattering signature responds to the whole column of ice, often expressed as ice water content integrated over depth, or ice water path (IWP; [19]). The higher the IWP is, the more depressed PCT at $85 \mathrm{GHz}$ tends to be. Thus, 85-GHz PCT is a good proxy indicator of convective intensity or lightning activity [13] [15] [17]. The Cumulative Distribution Functions (CDF) of minimum $85 \mathrm{GHz}$ Polarization Corrected Temperature (PCT) was computed for each of the 12 climate regions, and used to analyze the distributions of convective intensity of Radar Precipitation Features (RPF) inferred from the minimum $85 \mathrm{GHz}$ PCT.

\section{Spatial Distribution of 37-GHz and 85-GHz PCTs ICE Scattering Characteristics}

In this section, we have compared results from both 37- and 85-GHz PCTs for a particular season and identify regions susceptible to convective storms by their 37 - and 85 PCT values. Our examination of cases confirms that those most-intense pixels tend to occur roughly at the same location.

Figure 2 and Figure 3 indicate that only the Western Coast rainforest has a substantial part of data. The $37-\mathrm{GHz}$ PCT has values ranging from above $250 \mathrm{~K}$ whereas the $85-\mathrm{GHz}$ PCT values are above $229 \mathrm{~K}$ for the same region. This region had shown strong tendency for high flash counts from previous study. The adjacent ocean has lower minimum PCT values at $85-\mathrm{GHz}$ frequency, which is an indication of intense storm during DJF. Though large portion of the study regions are still without data, there are some areas adjacent to the ocean that can still be shown with data during MAM. During this season (MAM), as shown in Figure 4 and Figure 5, when thunderstorm and hence lightning activities are optimum as a result of the presence and influence of the AEJ, strong convective storms are already moving inland. This is shown by their minimum $85-\mathrm{GHz}$ PCT having values below $225 \mathrm{~K}$ and in some rainforest areas the PCT values are below $190 \mathrm{~K}$. The South Sudan Savannah (S_Sud_Sav) is a region dominated with light rain during MAM as indicated by their $37-$ and $85-\mathrm{GHz}$ PCT values $(>250 \mathrm{~K}$ 


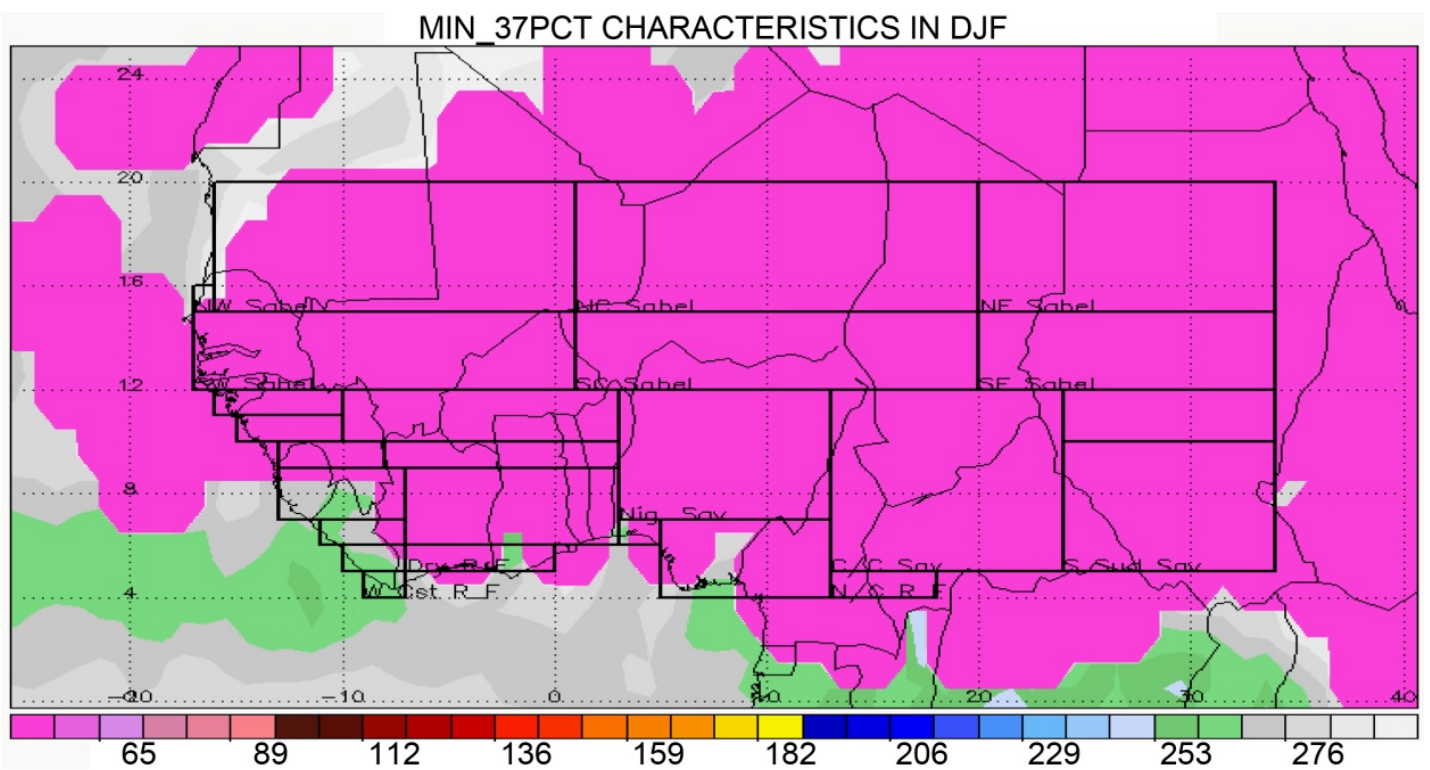

Figure 2. Showing spatial distribution of RPF with 37-GHz PCT ice scattering characteristics during DJF.

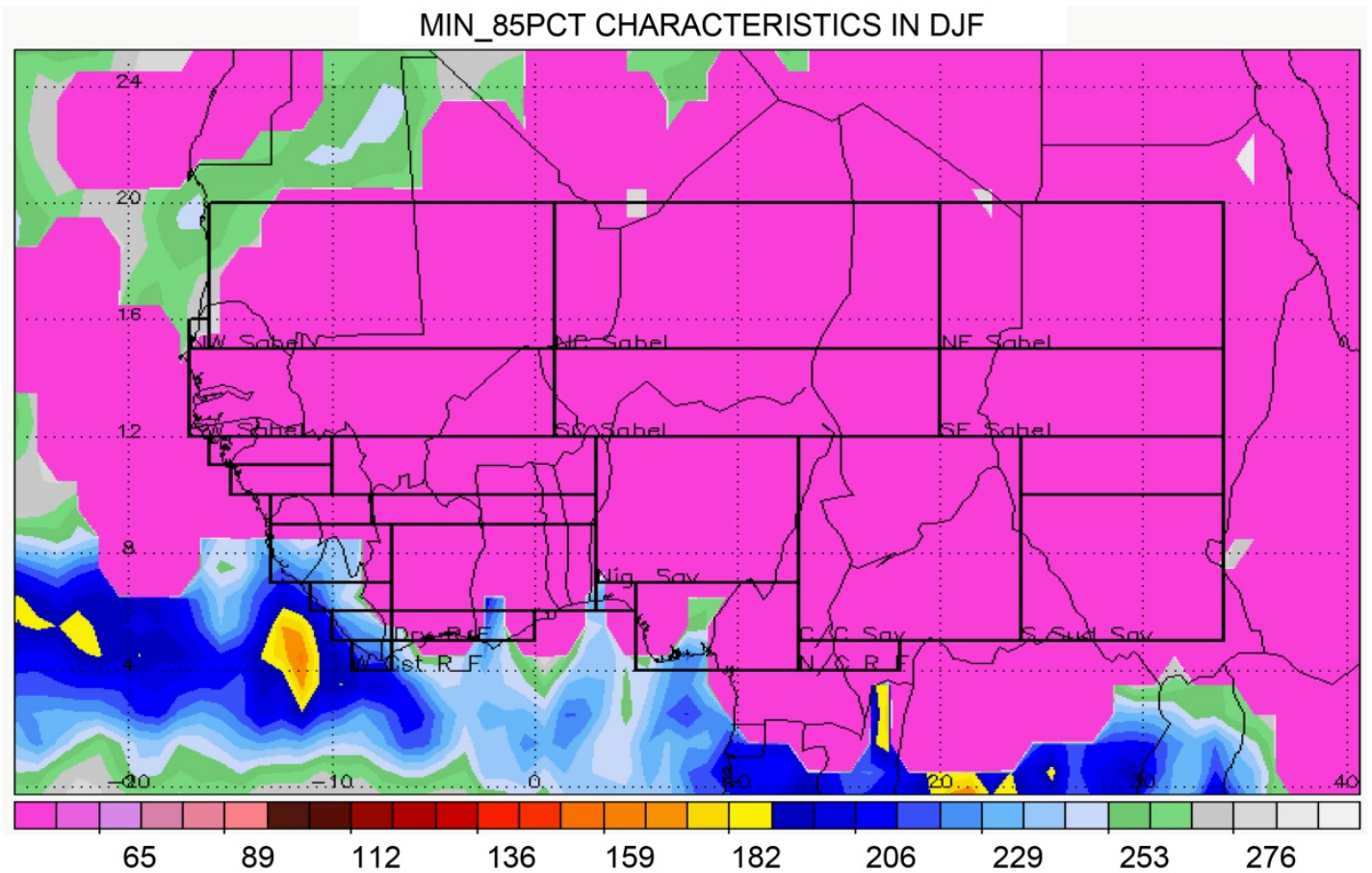

Figure 3. Showing spatial distribution of RPF with $85-\mathrm{GHz}$ PCT ice scattering characteristics during DJF.

for $85-\mathrm{GHz}$ PCT and $>275 \mathrm{~K}$ for $37-\mathrm{GHz}$ PCT). The central portion of Western Coast rainforest is indicative of light rain showers as shown by their 37 - and $85-\mathrm{GHz} \mathrm{PCT}$ values ( $>250 \mathrm{~K}$ for $85-\mathrm{GHz}$ PCT and >275 K for $37-\mathrm{GHz} \mathrm{PCT}$ ).

In JJA as shown in Figure 6 and Figure 7, there is no indication of ice particle scattering signal from the $37-\mathrm{GHz}$ frequency which is an indication that precipitation features in west Africa are without ice and are thus more generally produce warm rain but cold rain also are persistent in some areas. There are core areas with very low PCT values, as indicated by the arrows, for both $37-$ and $85-\mathrm{GHz}$ frequency. These areas are 
MIN_37PCT CHARACTERISTICS IN MAM

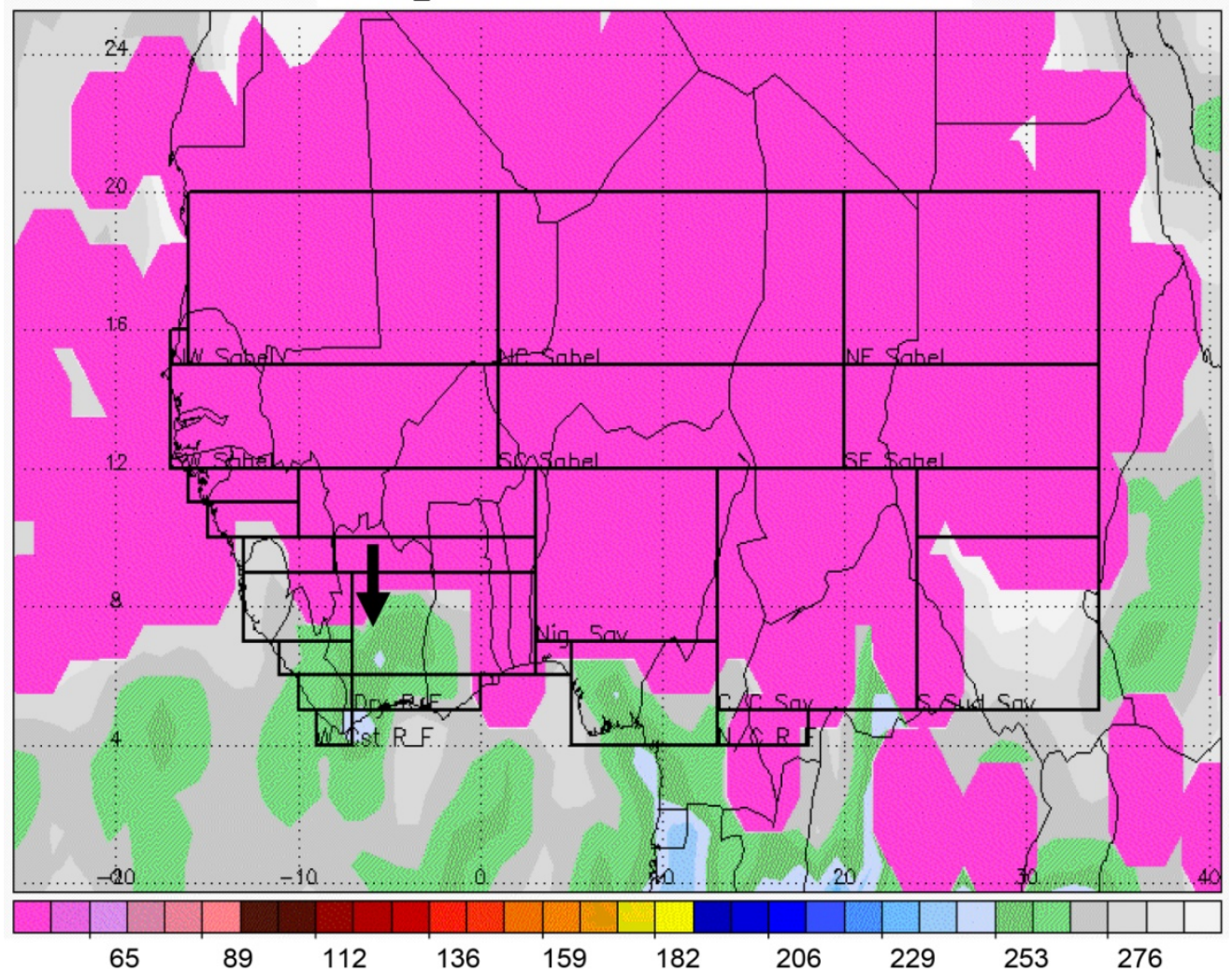

Figure 4. Showing spatial distribution of RPF with 37-GHz PCT ice scattering characteristics during MAM.

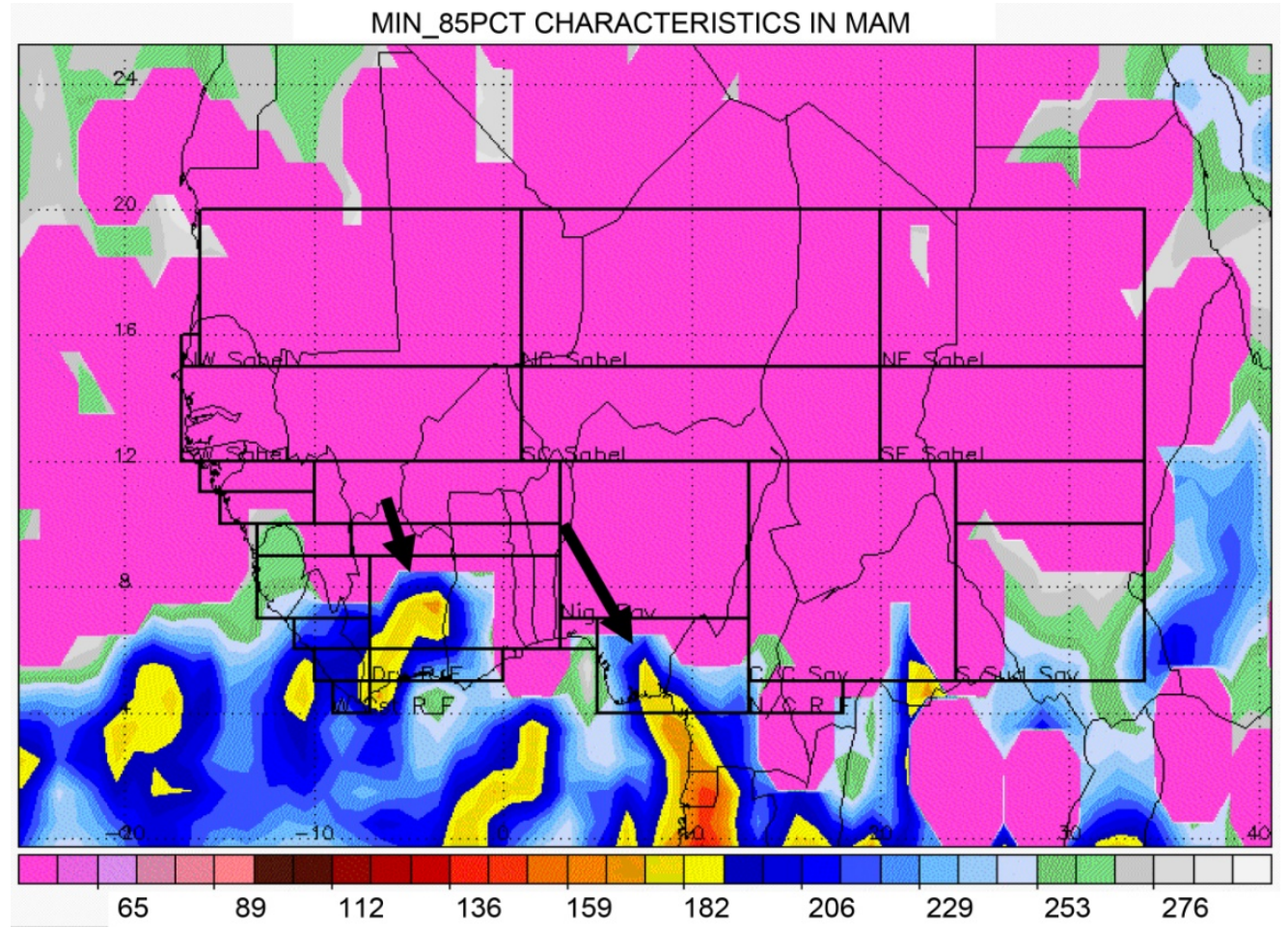

Figure 5. Showing spatial distribution of RPF with $85-\mathrm{GHz}$ PCT ice scattering characteristics during MAM. 


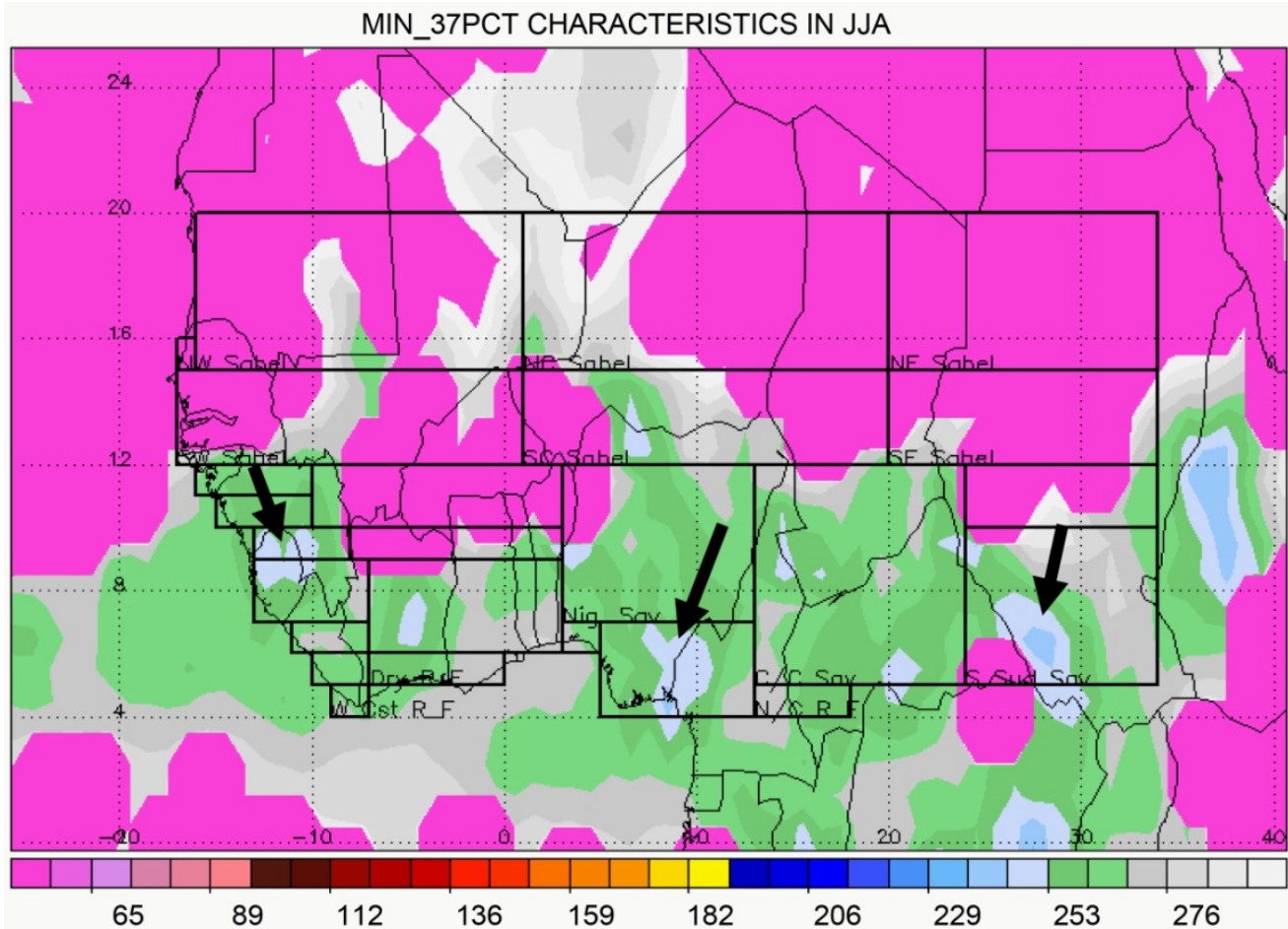

Figure 6. Showing spatial distribution of RPF with 37-GHz PCT ice scattering characteristics during JJA.

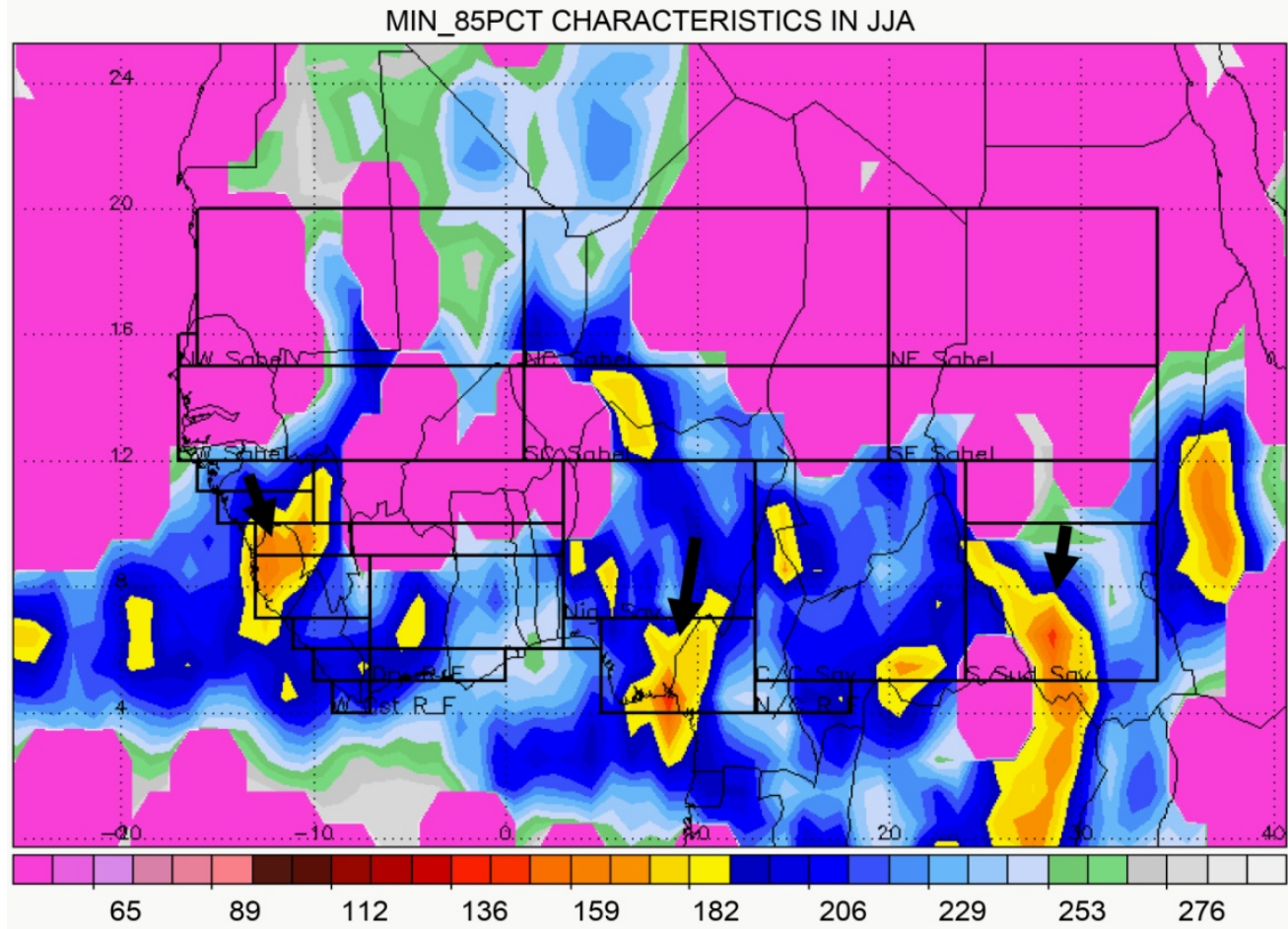

Figure 7. Showing spatial distribution of RPF with $85-\mathrm{GHz}$ PCT ice scattering characteristics during JJA.

likely to produce ice scattering signal and hence very cold rain or ice during JJA. In Figure 8 and Figure 9, during SON, the arrow pointed at a location in SC Sahel 


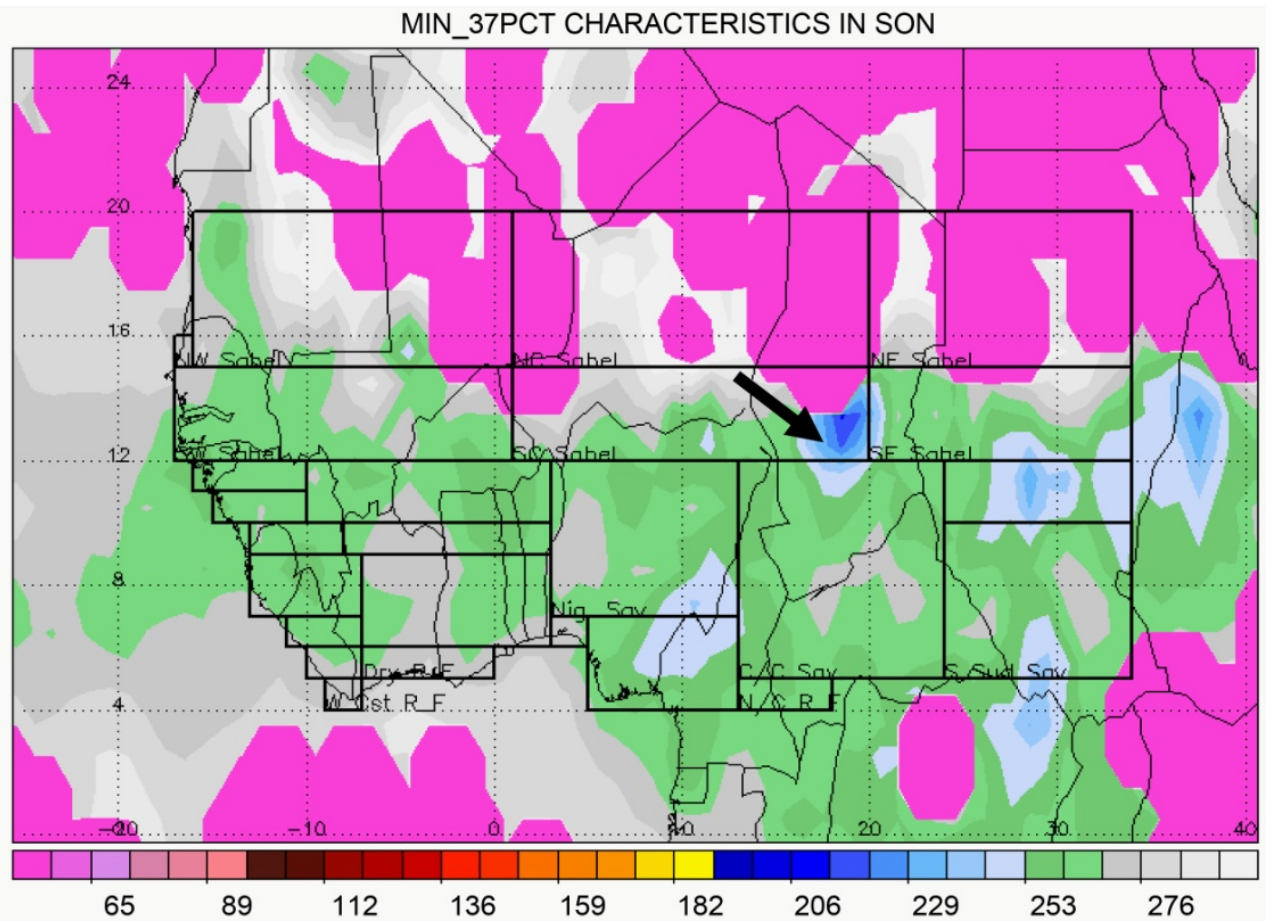

Figure 8. Showing spatial distribution of RPF with 37-GHz PCT ice scattering characteristics during SON.

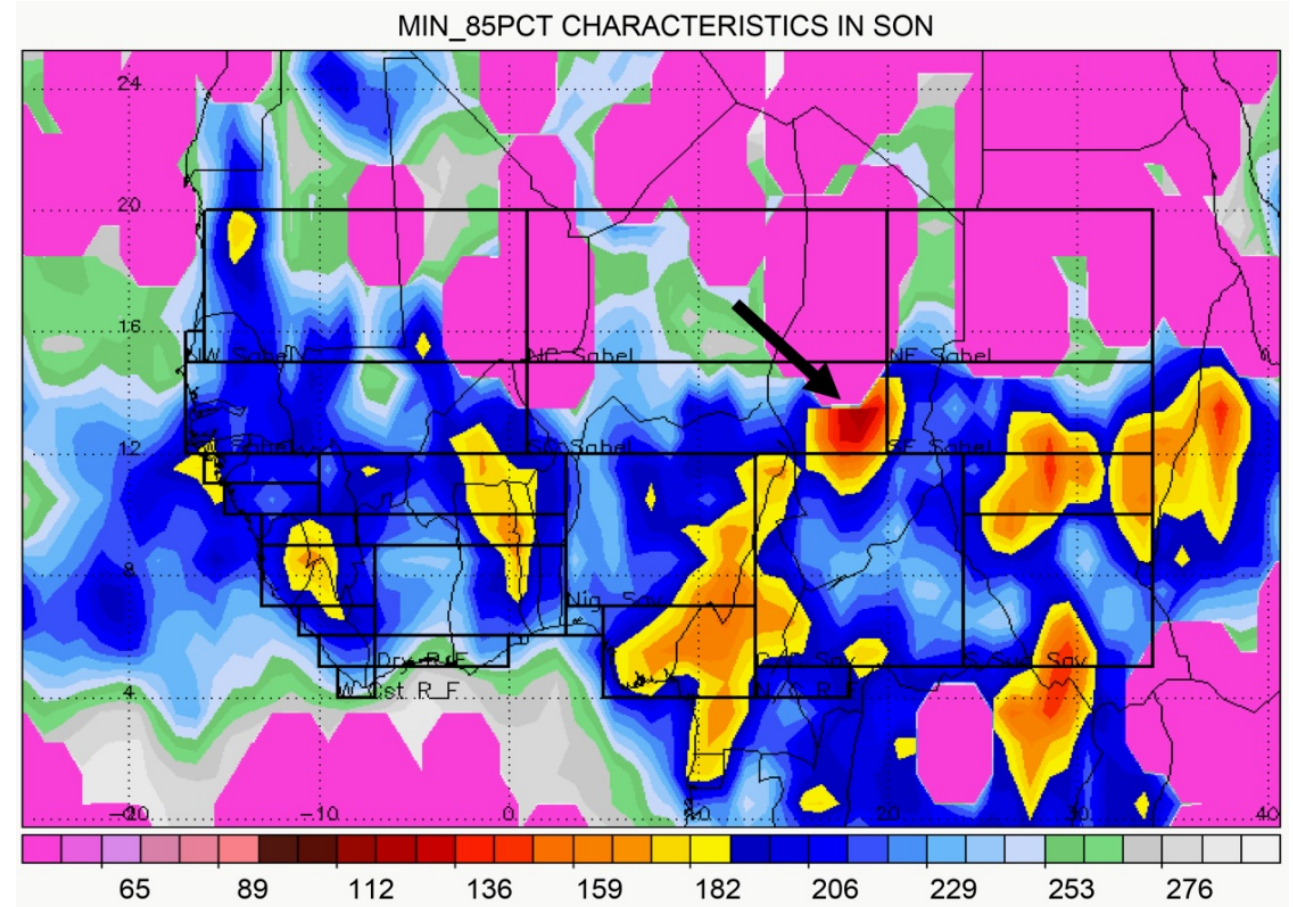

Figure 9. Showing spatial distribution of RPF with $85-\mathrm{GHz}$ PCT ice scattering characteristics during SON.

(South-Central Sahel) where there is strong indication of ice scattering signature and hence strong velocity updraft above the freezing level resulting in heavy rain or possibly storm cases, as will be shown in the next section. Surrounding regions marked with 
yellow label in that location and other similar locations, during JJA above and SON in Figure 8 and Figure 9, especially those represented by their $85-\mathrm{GHz}$ frequency indicate a large ice water path because it is more sensitive to smaller ice particles than the 37 $\mathrm{GHz}$. Low values at $37-\mathrm{GHz}$ tend to indicate that the feature contains larger ice particles, [12]. That is the basis for pointing the arrow at the same location at both frequencies (37-GHz and $85-\mathrm{GHz}$ PCT) during JJA and SON. Other locations in SON which indicated large ice water path using the $85-\mathrm{GHz}$ channel are not fully indicated by their $37-\mathrm{GHz}$ channel that such locations contains large ice particles.

\section{Radar Reflectivity Characteristics: Maximum Heights Attained by Echoes}

The arrows, in Figures 10-13, pointed at an area in the Dry rainforest that could have

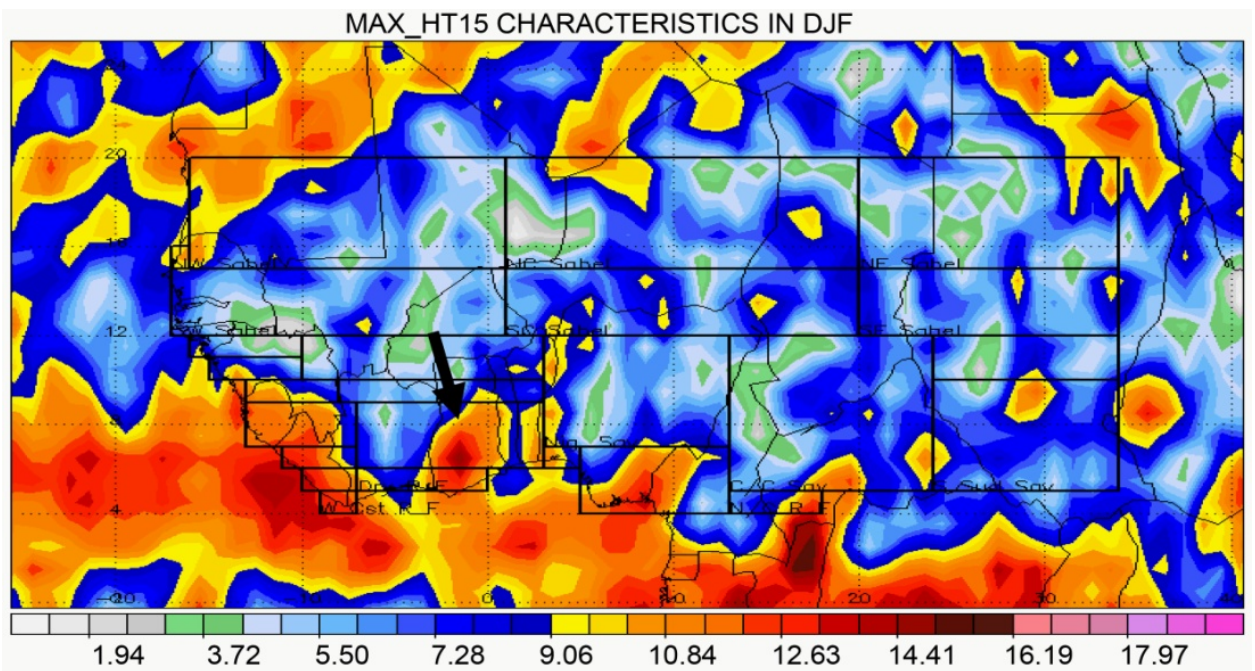

Figure 10. Showing spatial distribution of maximum heights attained by RPF with $15 \mathrm{dBZ}$ during DJF.

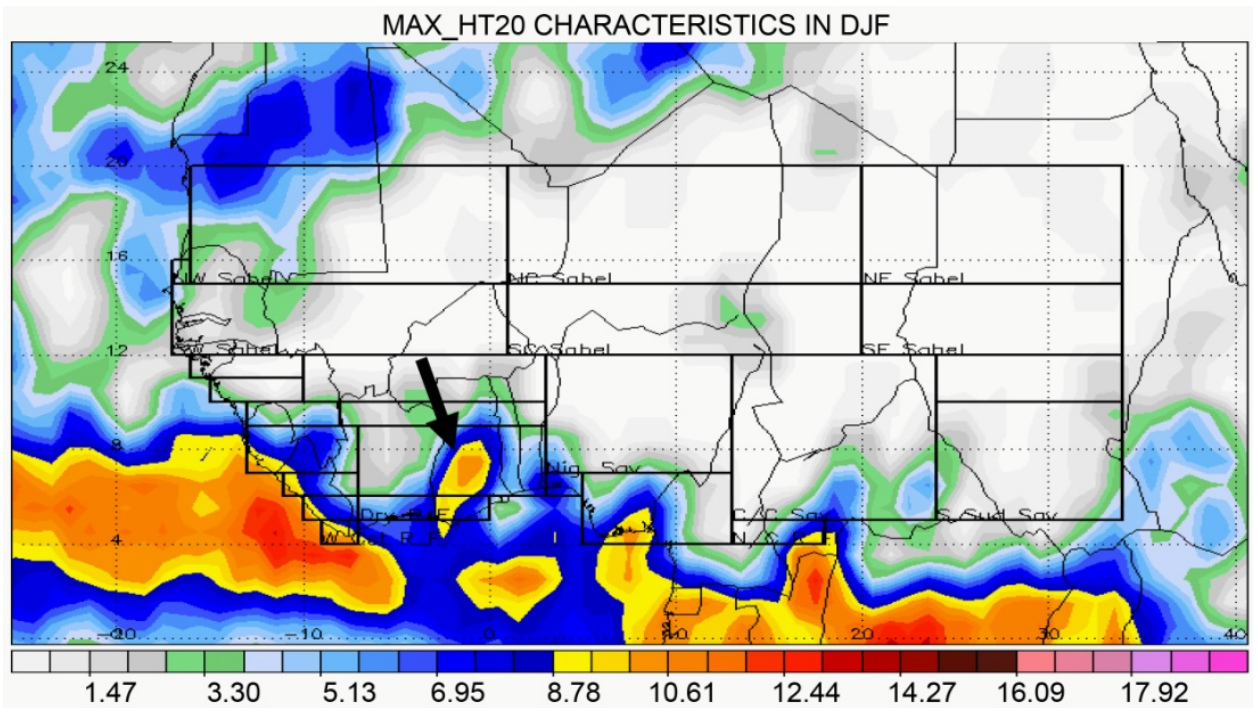

Figure 11. Showing spatial distribution of maximum heights attained by RPF with $20 \mathrm{dBZ}$ during DJF. 


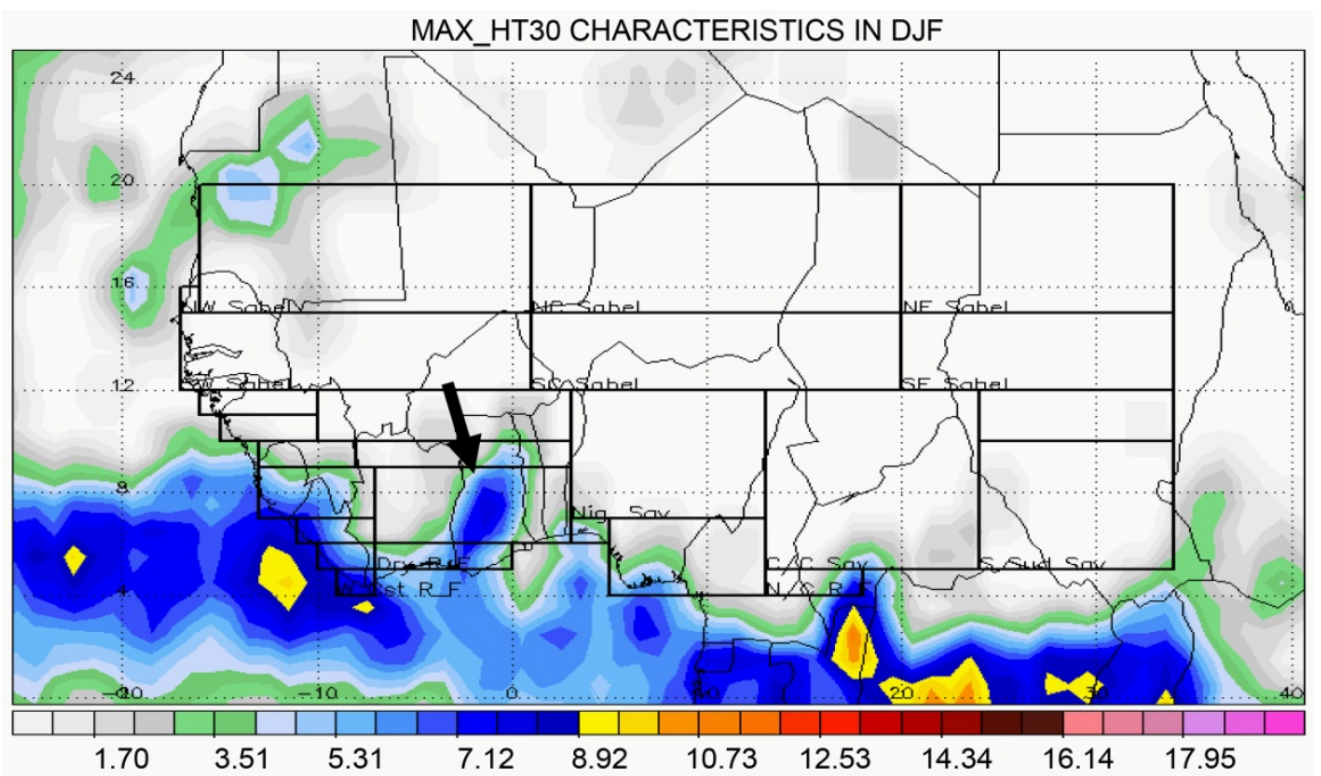

Figure 12. Showing spatial distribution of maximum heights attained by RPF with $30 \mathrm{dBZ}$ during DJF.

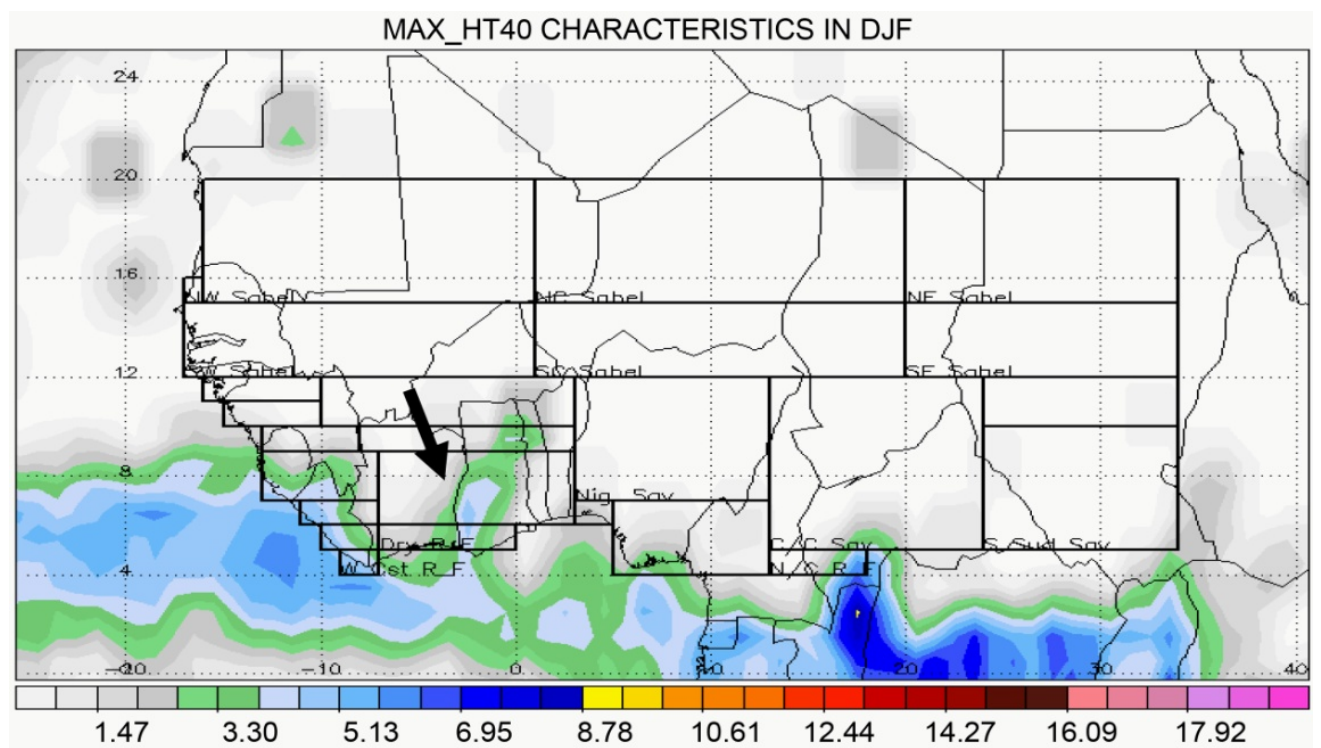

Figure 13. Showing spatial distribution of maximum heights attained by RPF with $40 \mathrm{dBZ}$ during DJF.

light, moderate or occasional heavy rains, during DJF, in which the 15, 20,30, and 40 reflectivity values attained heights above the freezing level. There is a clear tendency for the most intense storms over oceans to be adjacent to land, in locations favoring storm motion from land to ocean. Examples include tropical oceans west of Central America and West Africa, and subtropical oceans east of the southeastern United States, South America, Australia, and Africa, [17]. This is evident in DJF when the Inter-Tropical Discontinuity (ITD) is retreating southward close to it southernmost position.

It is noteworthy and not surprising that so much of the area (land areas close to the ocean) experiencing rainfall (at least $20-\mathrm{dB} Z$ radar reflectivity) has an $85-\mathrm{GHz}$ PCT between $182 \mathrm{~K}$ and $250 \mathrm{~K}$ (yellow and blue contour in Figure 5). [16] reasoned that storms containing higher $30 \mathrm{dBZ}$ heights likely contain more intense electric fields (and 
therefore more lightning), larger supercooled water and ice water contents; the second condition leading to lower $85-\mathrm{GHz}$ PCTs. Following this reasoning and the conditions highlighted in [17] which was based on [18] and physical reasoning outlined in many other studies, we simply classify such land areas or locations as a high storm area especially the pointed domains. This is in conformity with the fact that the presence of AEJ triggers thunderstorms and lightning activities in these areas during this season (MAM) as shown in Figures 14-17. Because the height attained by the $40 \mathrm{dBZ}$ at the Dry and Western-Coast rainforest domain is higher than that inside the Nigeria/Cameroon rainforest domain, it is obvious that the former is more susceptible to intense storm. During this season (MAM), the southern and northern Sahel regions have proxies for light rain as indicated by the height attained by their $15 \mathrm{dBZ}$ reflectivity value.

In JJA, as shown in Figures 18-21, most parts of the Sahel, except for North-East Sahel, are already having moderate rain. The maximum heights attained by the $30 \mathrm{dBZ}$ reflectivity in the affected Sahel regions are well above the freezing level and their 85 $\mathrm{GHz}$ PCT values as shown in Figure 6 and Figure 7 are below $250 \mathrm{~K}$ indicating that this system are very cold raining system in the affected regions. The arrow pointed at locations where the 85-GHz PCT values are below $190 \mathrm{~K}$ (from Figure 6 and Figure 7) and the maximum heights attained by their $20 \mathrm{dBZ}, 30 \mathrm{dBZ}$ and $40 \mathrm{dBZ}$ reflectivity values are well above the freezing level. These locations are susceptible to intense storms during this season and most likely to cause flooding depending on the terrain or

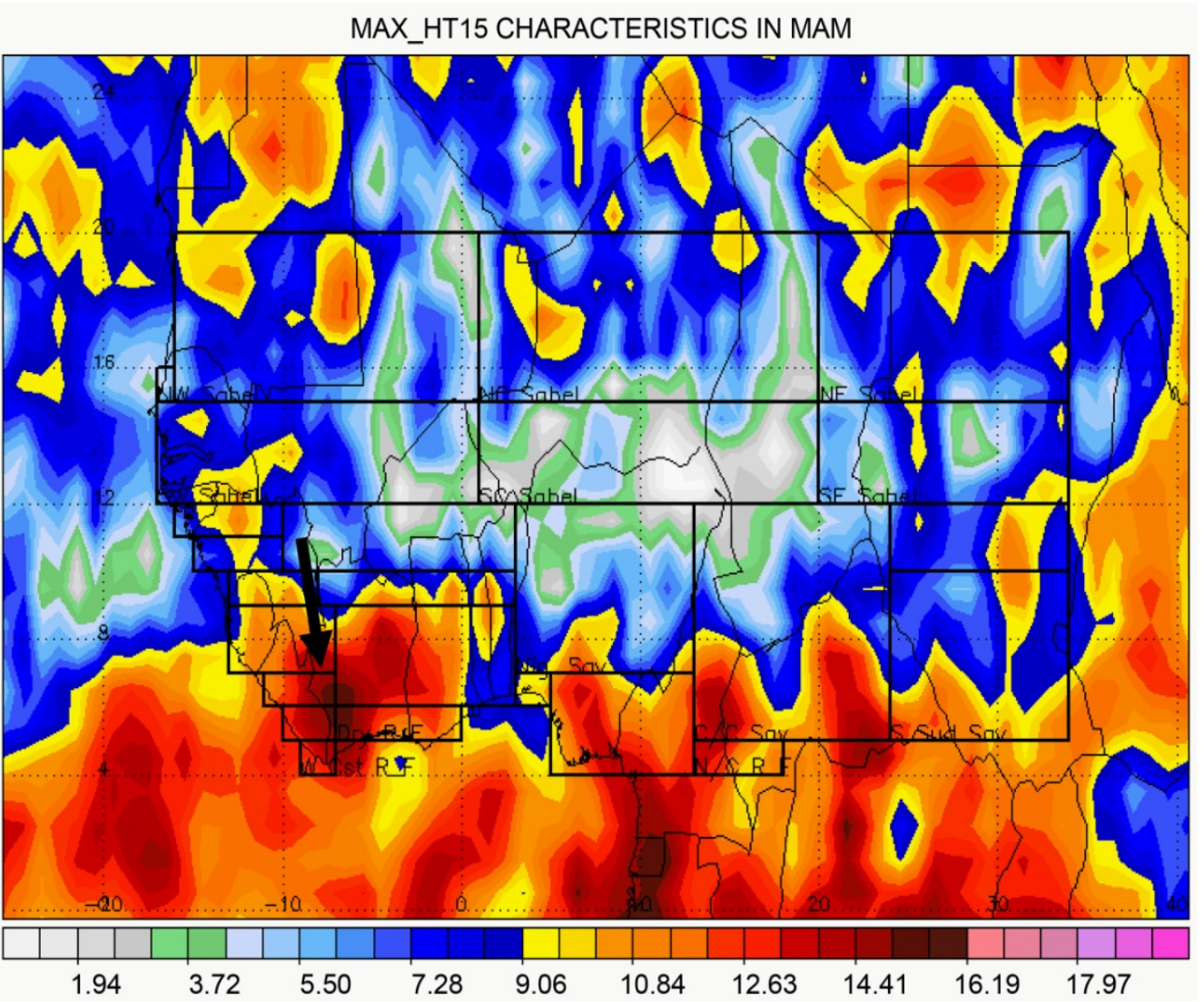

Figure 14. Showing spatial distribution of maximum heights attained by RPF with $20 \mathrm{dBZ}$ during MAM. 


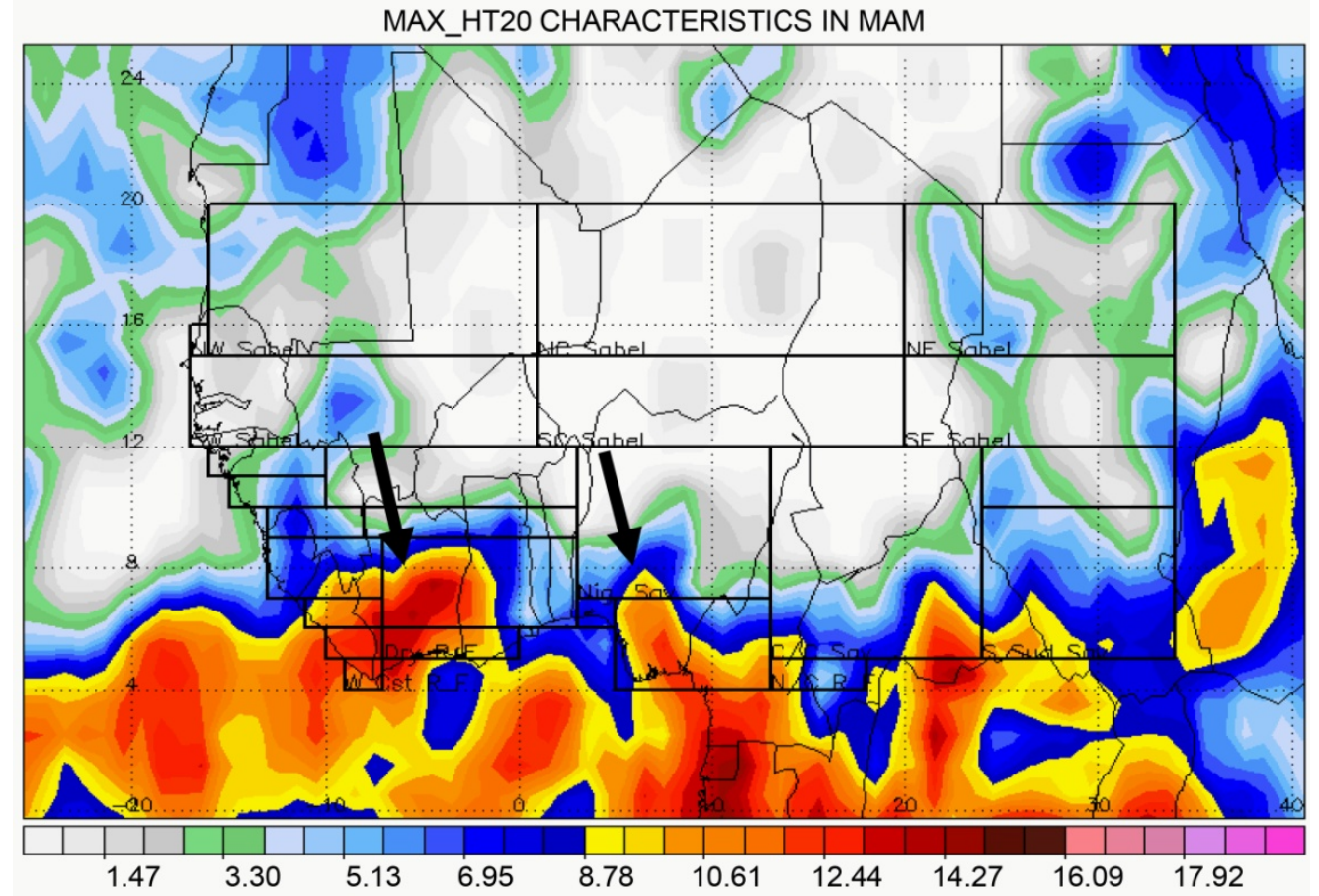

Figure 15. Showing spatial distribution of maximum heights attained by RPF with $20 \mathrm{dBZ}$ during MAM.

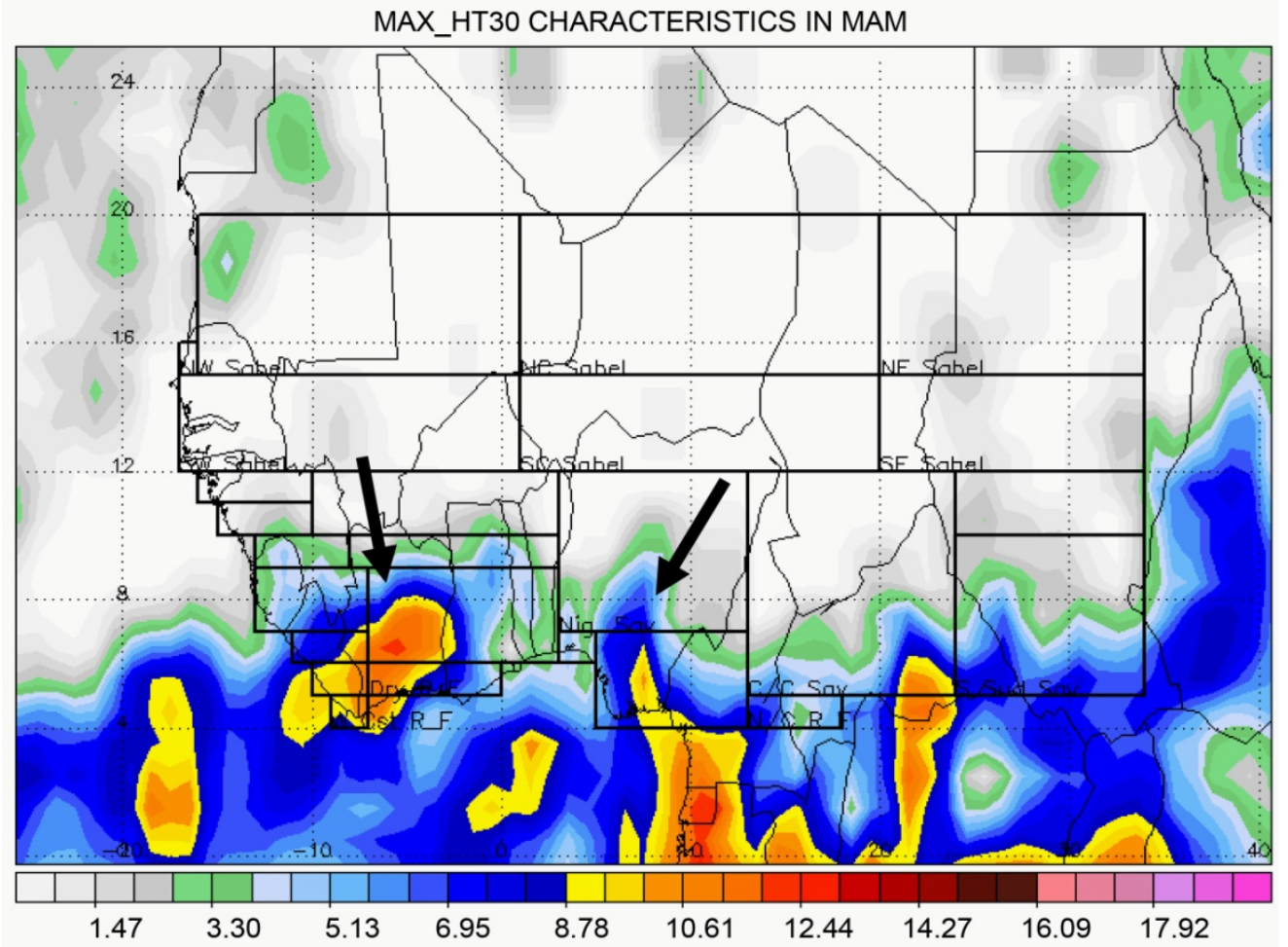

Figure 16. Showing spatial distribution of maximum heights attained by RPF with $30 \mathrm{dBZ}$ during MAM.

topography of the area. There is no tendency for intense storms in other parts of the rainforest and savannah since the maximum height attained by their $40 \mathrm{dBZ}$ reflectivity 


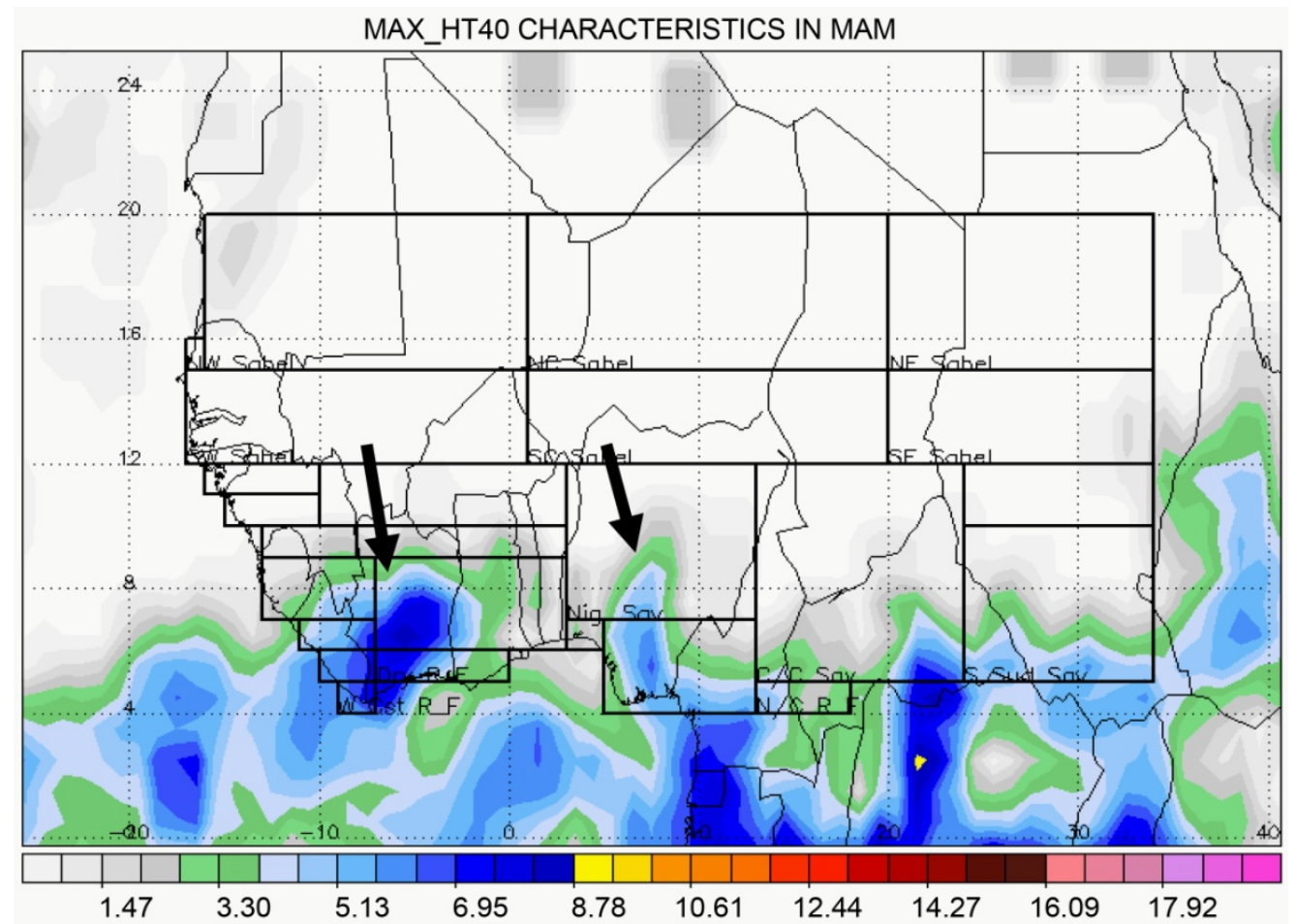

Figure 17. Showing spatial distribution of maximum heights attained by RPF with $40 \mathrm{dBZ}$ during MAM.

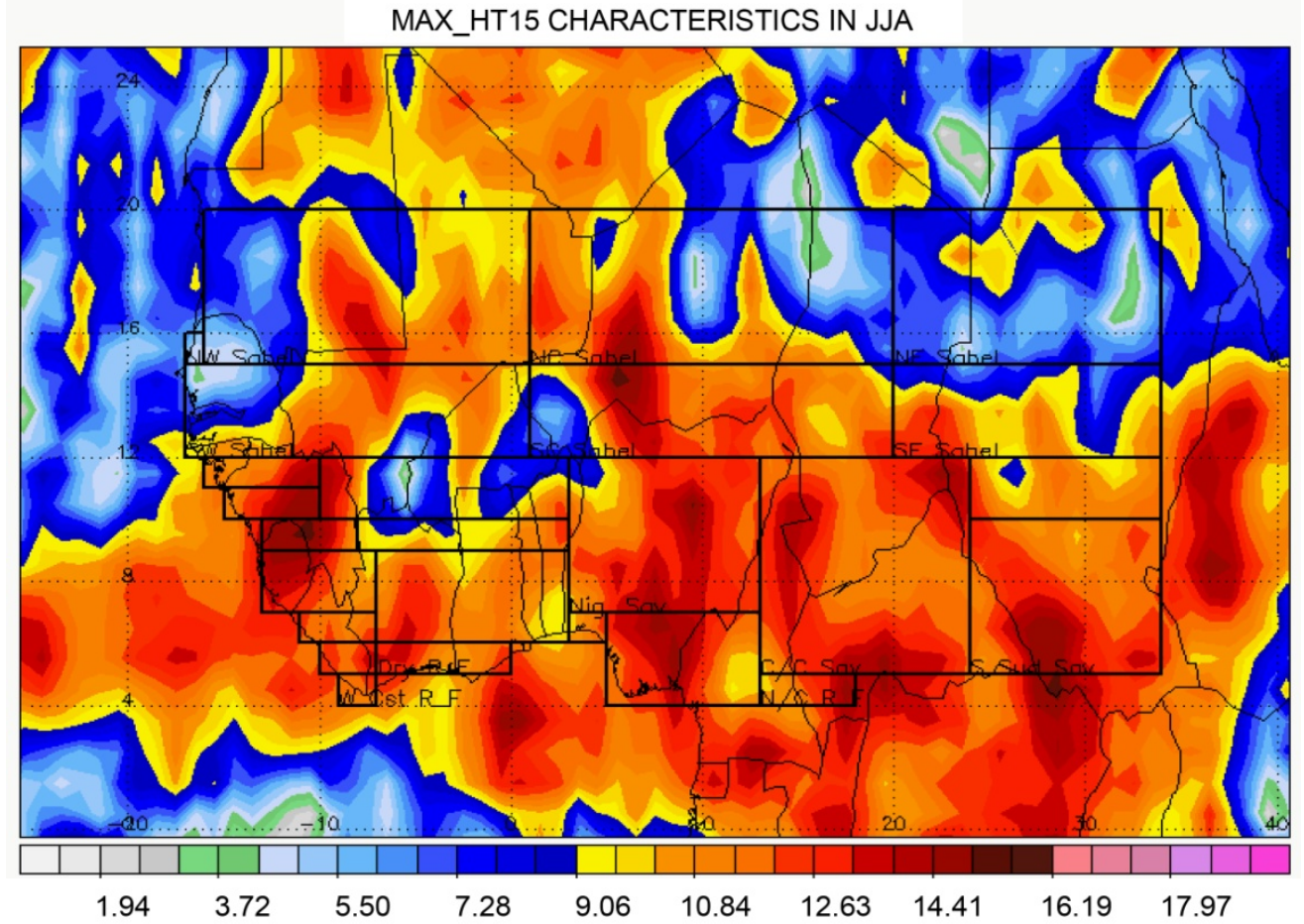

Figure 18. Showing spatial distribution of maximum heights attained by RPF with $15 \mathrm{dBZ}$ during JJA.

is just around the freezing level but these regions are experiencing cold (from Figure 6 and Figure 7)) and moderate rain as seen by the maximum height attained by their 30 $\mathrm{dBZ}$ reflectivity. Cold light rain or showers should be expected in north-east Sahel as 


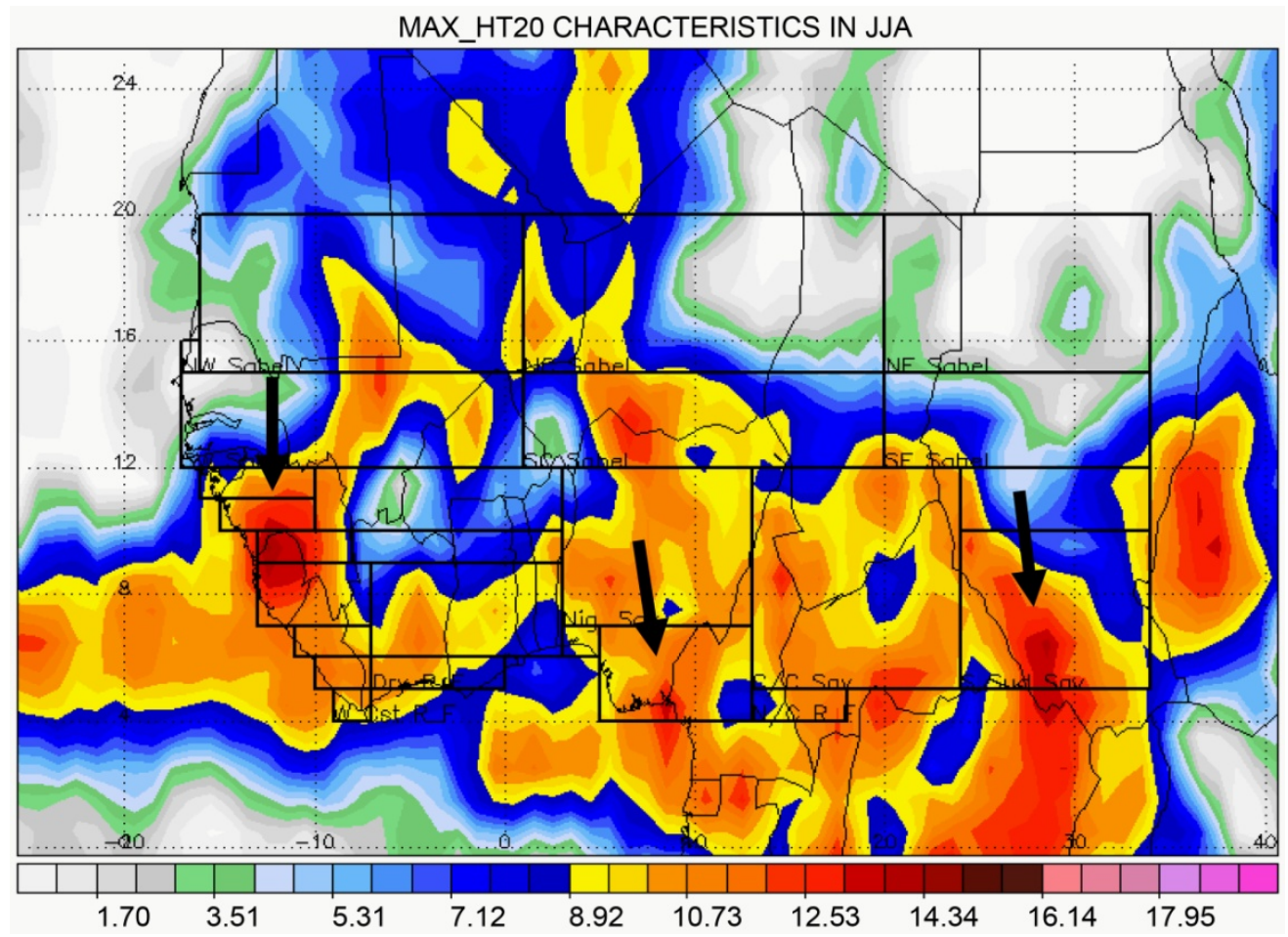

Figure 19. Showing spatial distribution of maximum heights attained by RPF with $20 \mathrm{dBZ}$ during JJA.

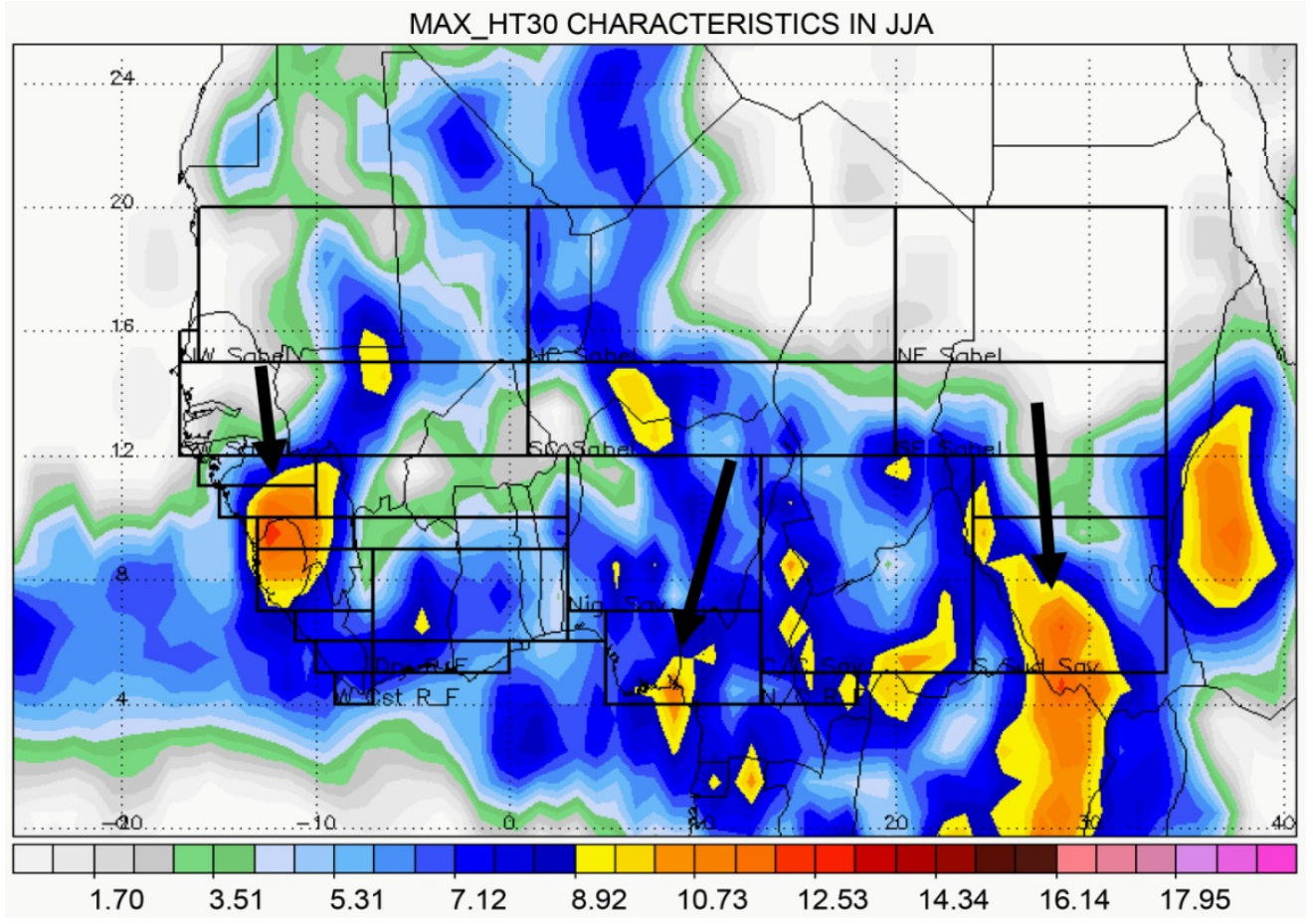

Figure 20. Showing spatial distribution of maximum heights attained by RPF with $30 \mathrm{dBZ}$ during JJA.

depicted by the maximum height attained by $15 \mathrm{dBZ}$ reflectivity. The $15 \mathrm{dBZ}$ reflectivity is below the minimum detectable signal $(\sim 17 \mathrm{dBZ})$ of the precipitation radar hence cannot be fully reliable.

There is always a similarity, in plot pattern, between regions associated with cold rain 
MAX_HT40 CHARACTERISTICS IN JJA

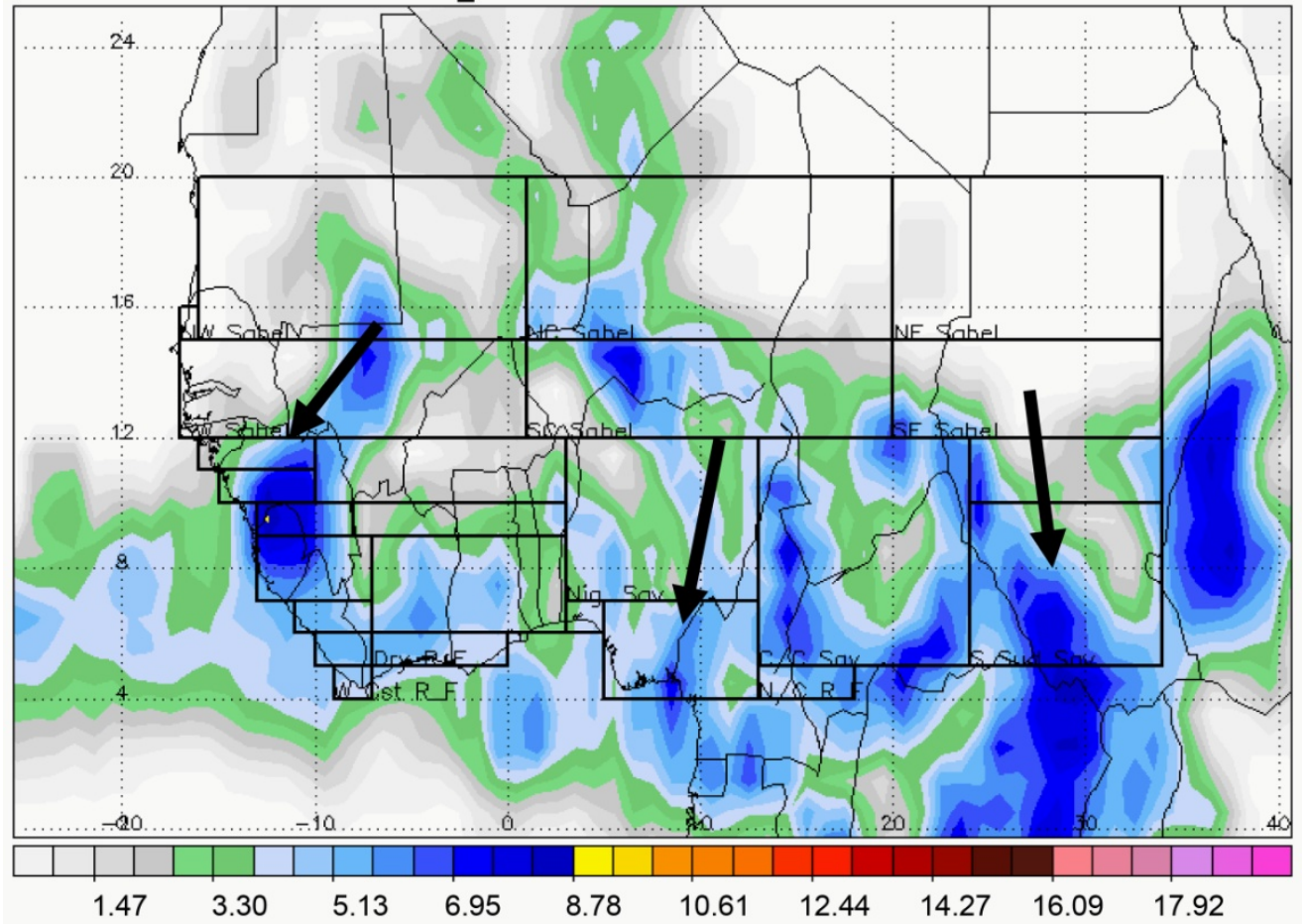

Figure 21. Showing spatial distribution of maximum heights attained by RPF with $40 \mathrm{dBZ}$ during JJA.

as depicted by the $85-\mathrm{GHz}$ PCT values and regions associated with strong updraft as depicted by the maximum height attained by the $30 \mathrm{dBZ}$ reflectivity. This is saying, theoretically, that a relationship can be established between these two parameters for storm scale measurements. Details of possible relationships can be found from [6]. The plot, in Figures 22-25, showed a location on the eastern part of south-central Sahel where the maximum height attained by the $30 \mathrm{dBZ}$ reflectivity is above $12 \mathrm{~km}$ and the maximum height attained by the $40 \mathrm{dBZ}$ reflectivity is above $10 \mathrm{~km}$ during SON. Also this location has very low minimum $37-\mathrm{GHz}$ and $85-\mathrm{GHz}$ PCTs, from Figure 8 and Figure 9 in section 3.1. The storm scale for this location could be destructive and possibly flood events might be the order of the day during this season (SON) depending on the terrain or topography of the area.

\section{Distributions of Convective Intensity Inferred from Minimum $85 \mathrm{GHz}$ Polarization Corrected Temperature (PCT)}

In this section, it is necessary to consider additional information from the $85-\mathrm{GHz}$ brightness temperature by analyzing the Cumulative Distribution Functions (CDFs) of this parameter for the twelve regions under investigation as shown in Figure 26.

The Western-Coast rainforest had marginal potential for convection during DJF with at least $30 \%$ of its $85 \mathrm{GHz}$ PCT $<225 \mathrm{~K}$ (a $225 \mathrm{~K}$ value is marginally suggestive of convection) and about $50 \%$ of its $85 \mathrm{GHz}$ PCT $>250 \mathrm{~K}$ (a $250 \mathrm{~K}$ value is often associated with stratiform precipitation). Other rainforest and savannah regions (except South Sudan savannah) are prone to convective activities but with a lesser percentage. All the Sahel and South Sudan Savannah have minimum $85 \mathrm{GHz}$ PCT $>250 \mathrm{~K}$ in DJF. 


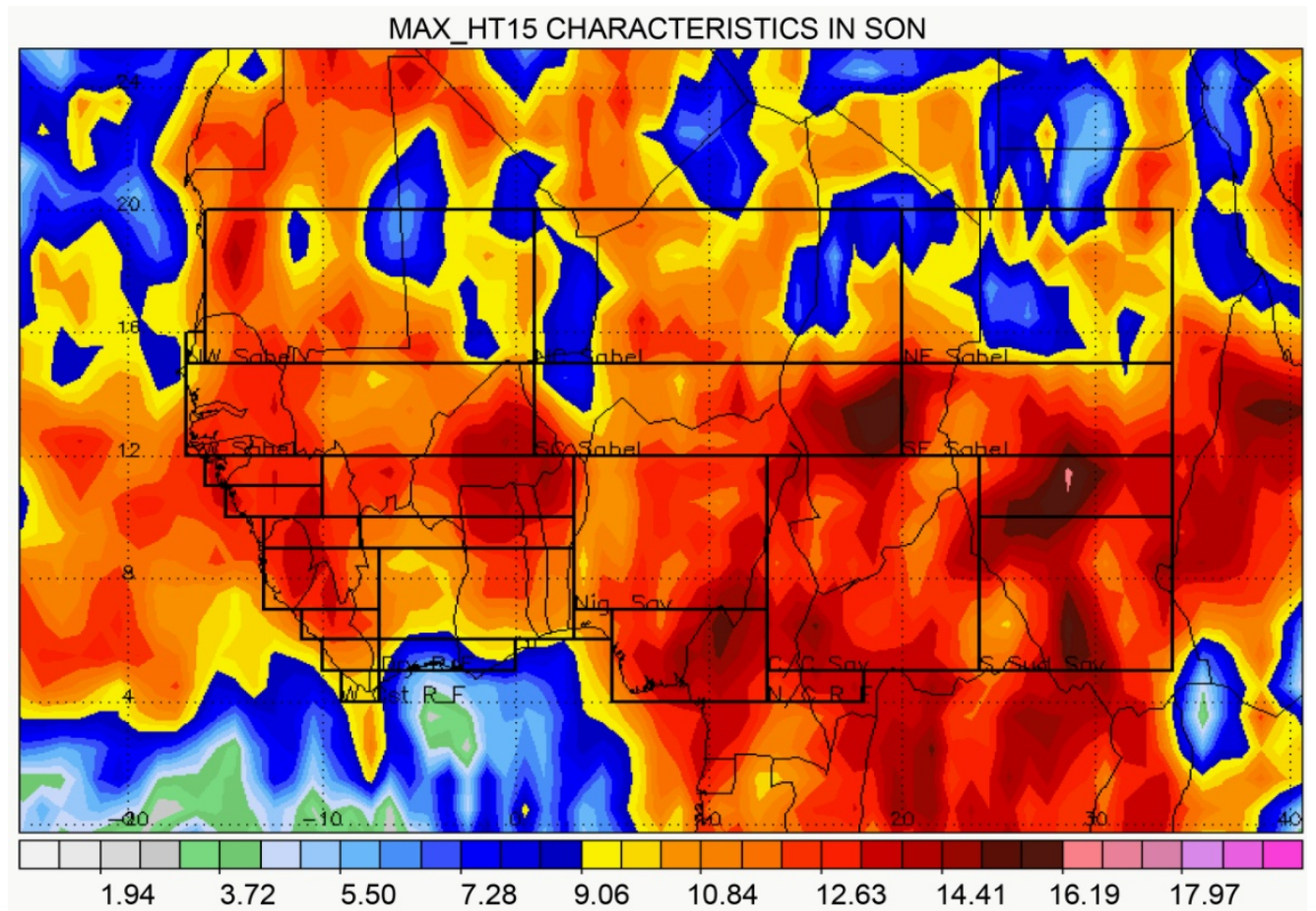

Figure 22. Showing spatial distribution of maximum heights attained by RPF with $15 \mathrm{dBZ}$ during SON.

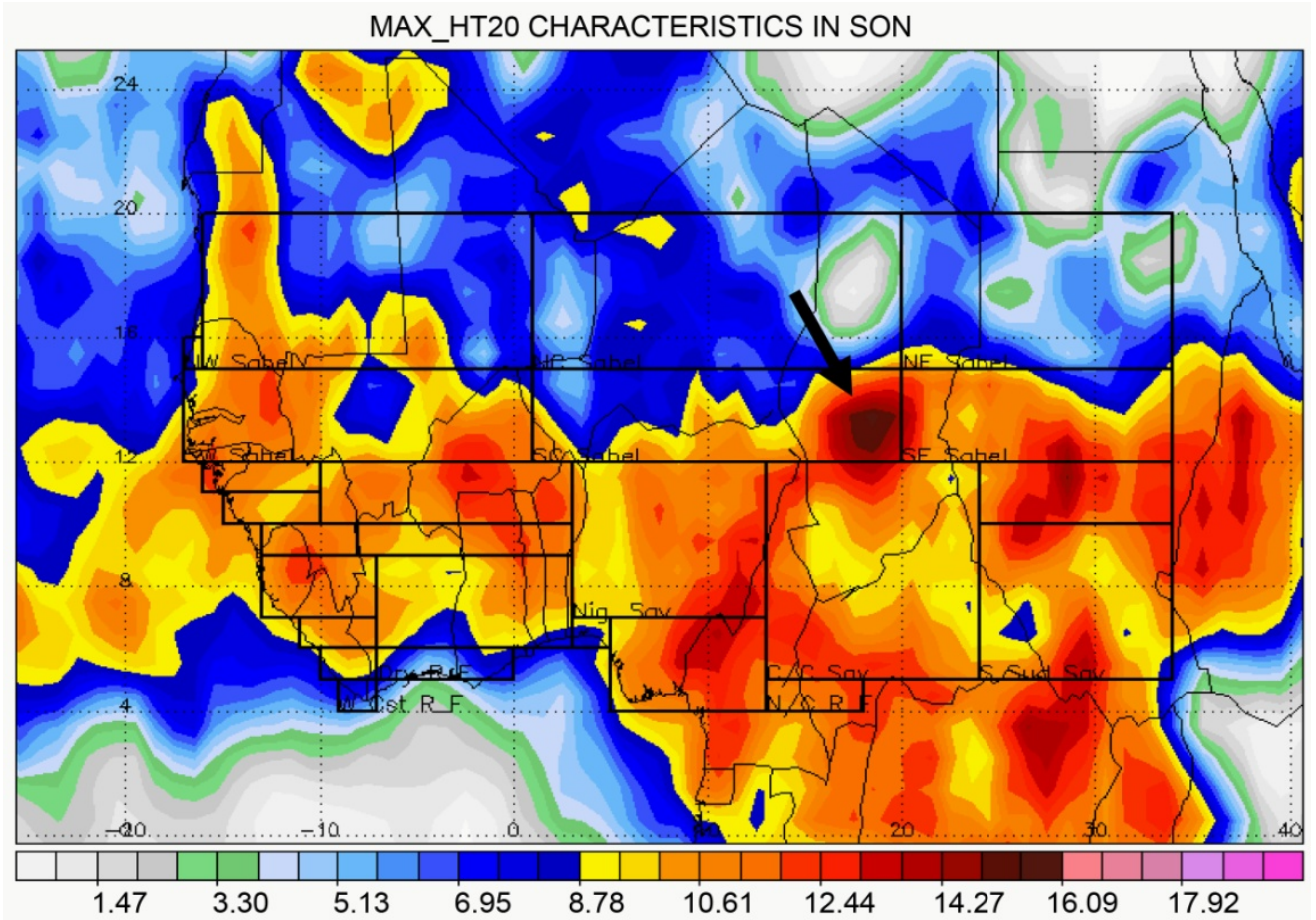

Figure 23. Showing spatial distribution of maximum heights attained by RPF with $20 \mathrm{dBZ}$ during SON.

In MAM, the situation is a little different especially with south Sudan savannah and south-east Sahel (Figure 27). They carry some percentage of convective intensity in their precipitation systems. In tropical continental convection, the probability of LIS- 


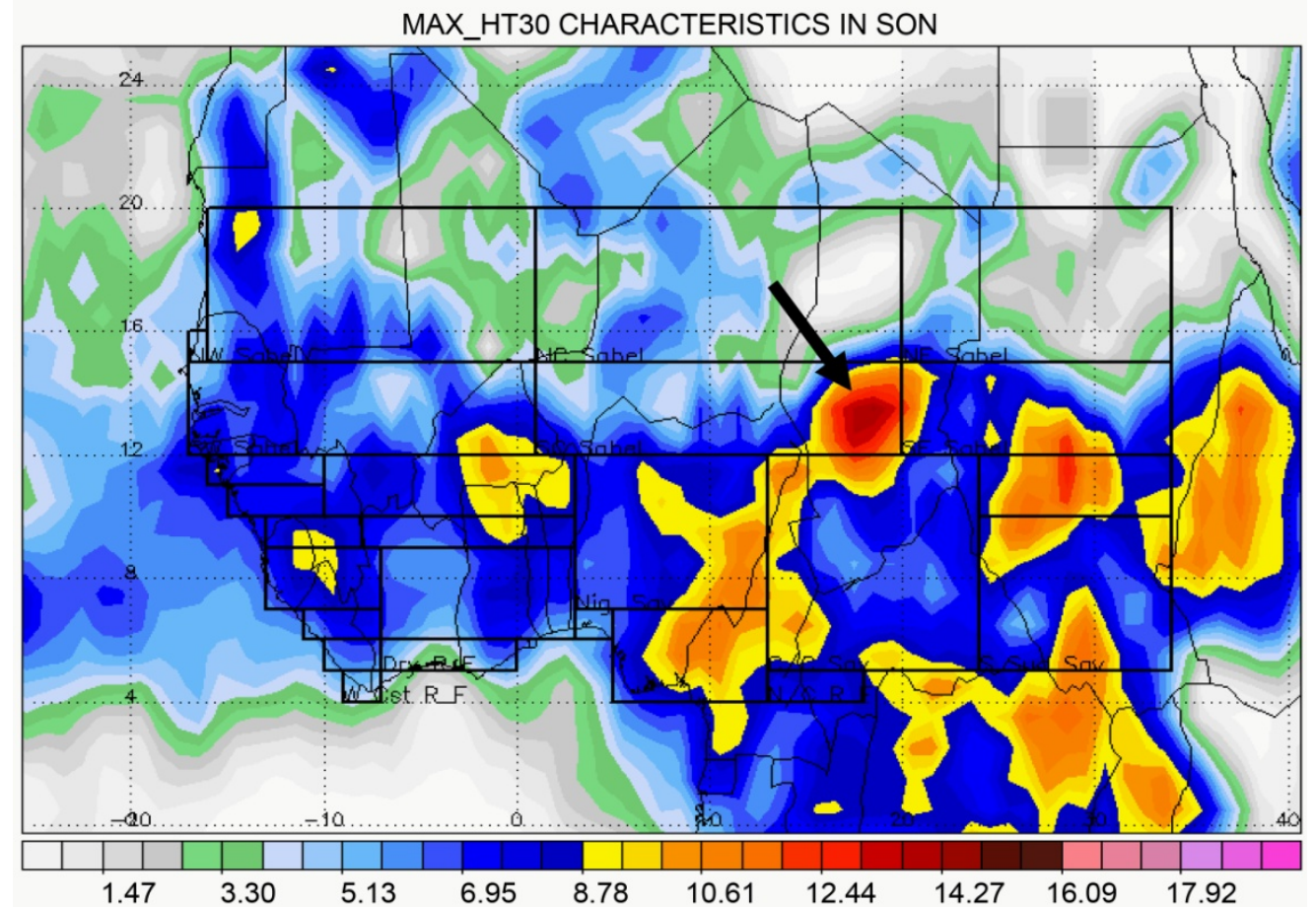

Figure 24. Showing spatial distribution of maximum heights attained by RPF with $30 \mathrm{dBZ}$ during SON.

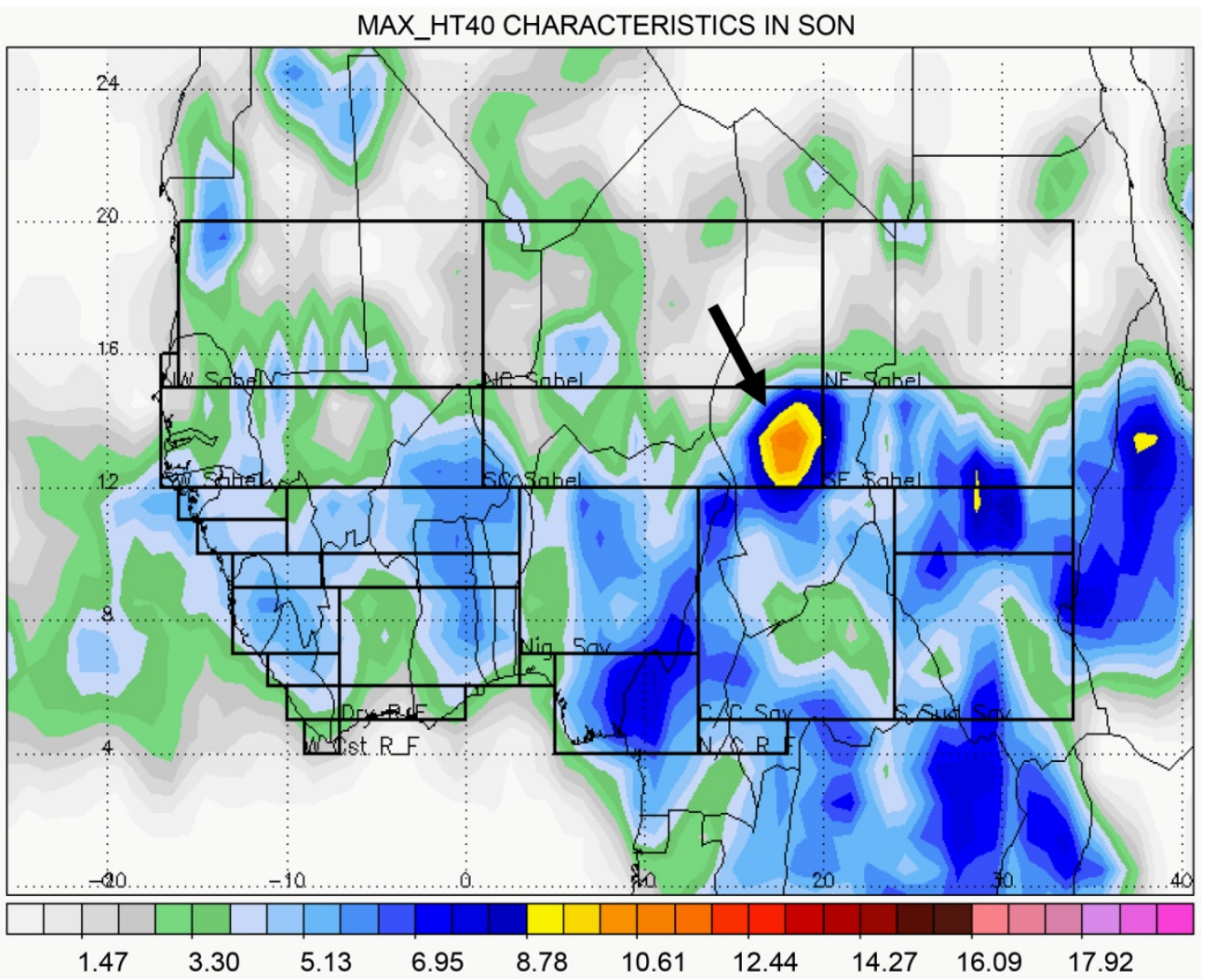

Figure 25. Showing spatial distribution of maximum heights attained by RPF with $40 \mathrm{dBZ}$ during SON.

observed lightning (at least $\sim 1$ flash $\min ^{-1}$ ) begins to increase rapidly as the $85-\mathrm{GHz}$ 


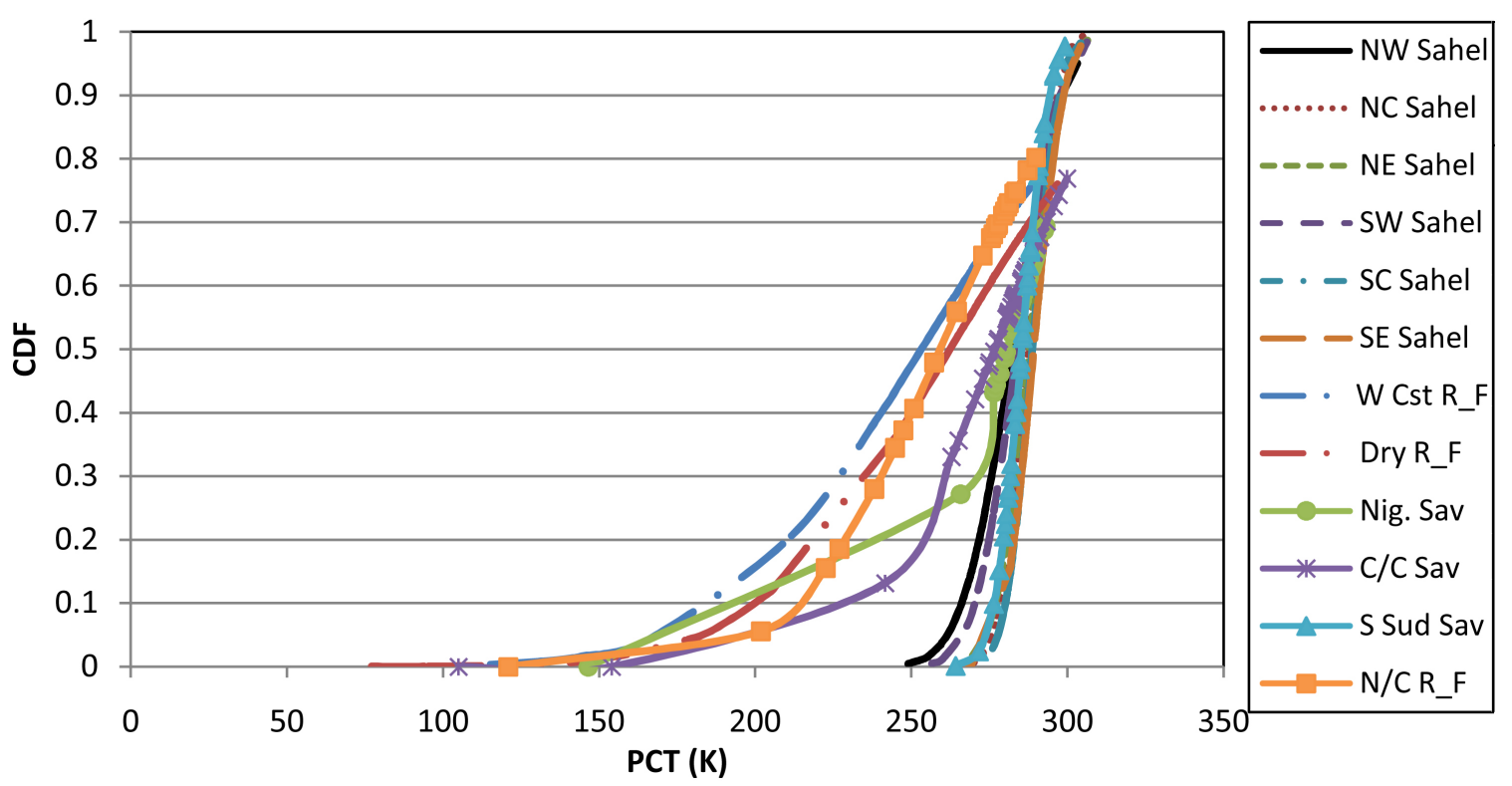

Figure 26. Convective intensity inferred from minimum $85-\mathrm{GHz}$ pct during DJF.

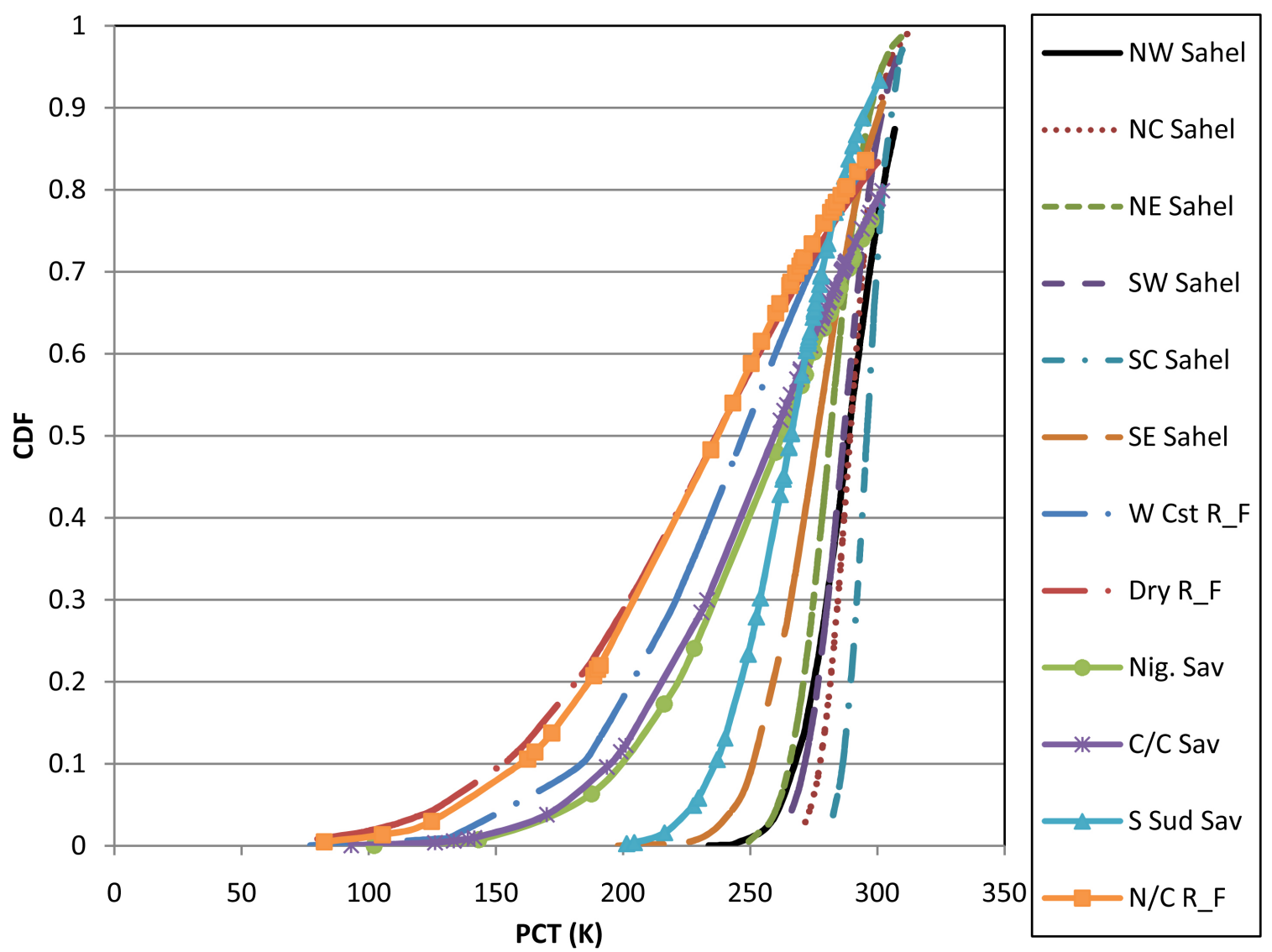

Figure 27. Convective intensity inferred from minimum $85-\mathrm{GHz}$ pct during MAM.

polarization corrected temperature (PCT) decreases below $260 \mathrm{~K}$ or $37-\mathrm{GHz}$ PCT decreases below $275 \mathrm{~K}$ [6]. With these low brightness temperatures, the occurrence of lightning and hence thunderstorms is nearly a certainty in tropical continental convec- 
tion and hence West African continental convection. None of the Sahel and south Sudan savannah has $85 \mathrm{GHz}$ PCT less than $200 \mathrm{~K}$ but the south Sudan savannah and south-east Sahel have some percentage of convective properties. From the plot, it further revealed that Nigeria/Cameroon rainforest and dry rainforest had very similar curvilinear patterns and constitute over $60 \%$ of $85 \mathrm{GHz} \mathrm{PCT}<250 \mathrm{~K}$ during this season. Whereas Nigeria savannah and Chad/Central African republic savannah had about $45 \%$ of $85 \mathrm{GHz}$ PCT $<250 \mathrm{~K}$, thus a greater percentage of lightning and hence thunderstorm activities are observed in descending order in dry rainforest, Nigeria/Cameroon rainforest, western-coast rainforest, Chad/Central African republic savannah and Nigeria savannah.

Figure 27 further revealed that, during MAM, most of the Sahel doesn't experience lightning and thunderstorms activities since their 85-GHz PCT rarely falls below $250 \mathrm{~K}$. This is attributed to the fact that the African Easterly Jet (AEJ) is located in the south of the ITD (which is around $10^{\circ} \mathrm{N}$ ) and hence triggers lightning and thunderstorm activities in the rainforest and savannah regions.

Figure 28 is in agreement with the fact that the monsoon or moisture layer is very deep during this season (JJA). A very large percentage of the $85-\mathrm{GHz}$ PCT is less than $250 \mathrm{~K}$ for all the regions except for north-east Sahel. The percentage of $85-\mathrm{GHz}$ PCT that fell below $200 \mathrm{~K}$ and $150 \mathrm{~K}$ are good enough to bring deep convective systems in the affected regions. North-East Sahel agrees with what was observed in Figures 18-21, in the previous section. That is, NE Sahel is a rain-free or region dominated with very

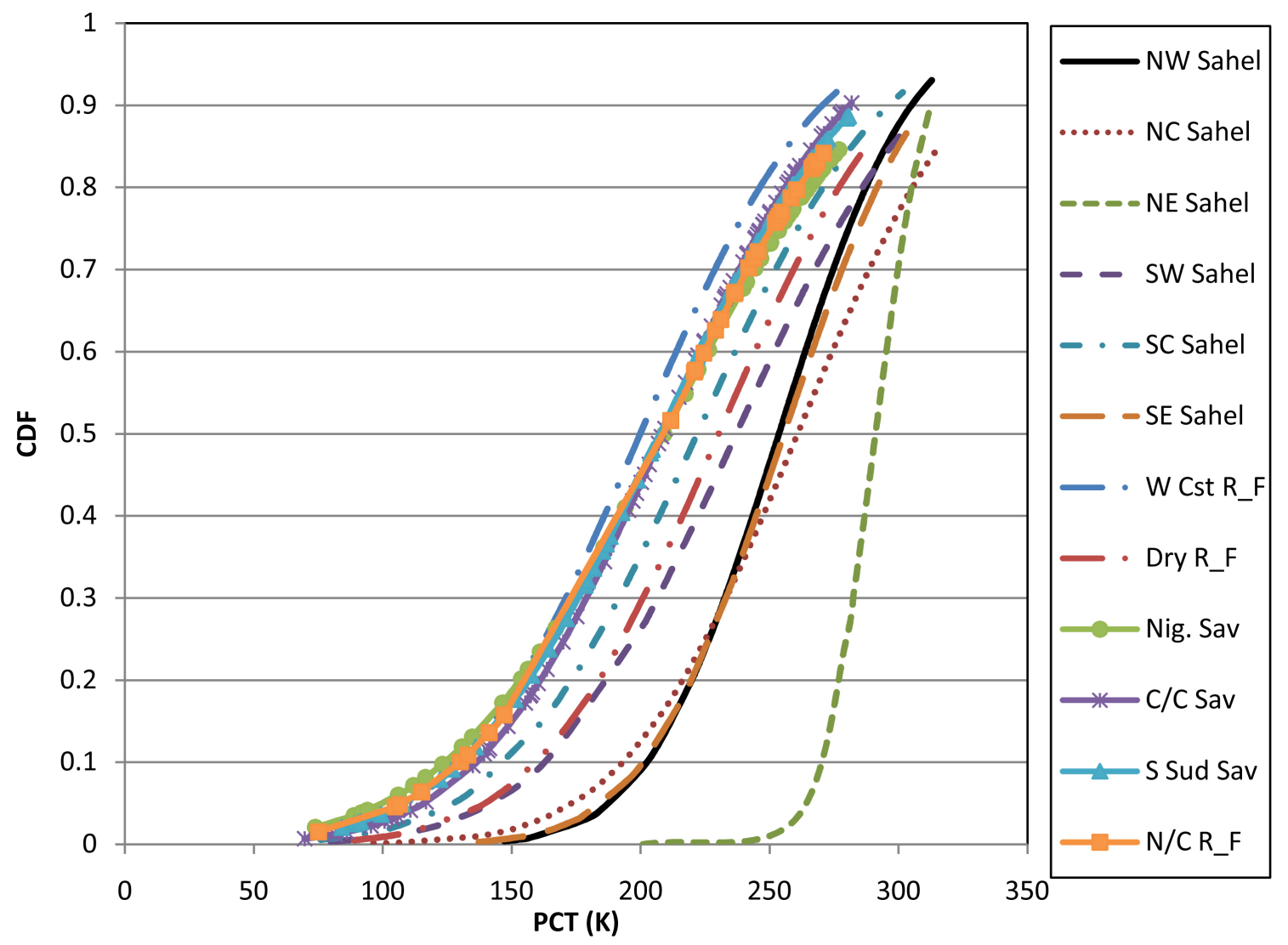

Figure 28. Convective intensity inferred from minimum $85-\mathrm{GHz}$ pct during JJA. 


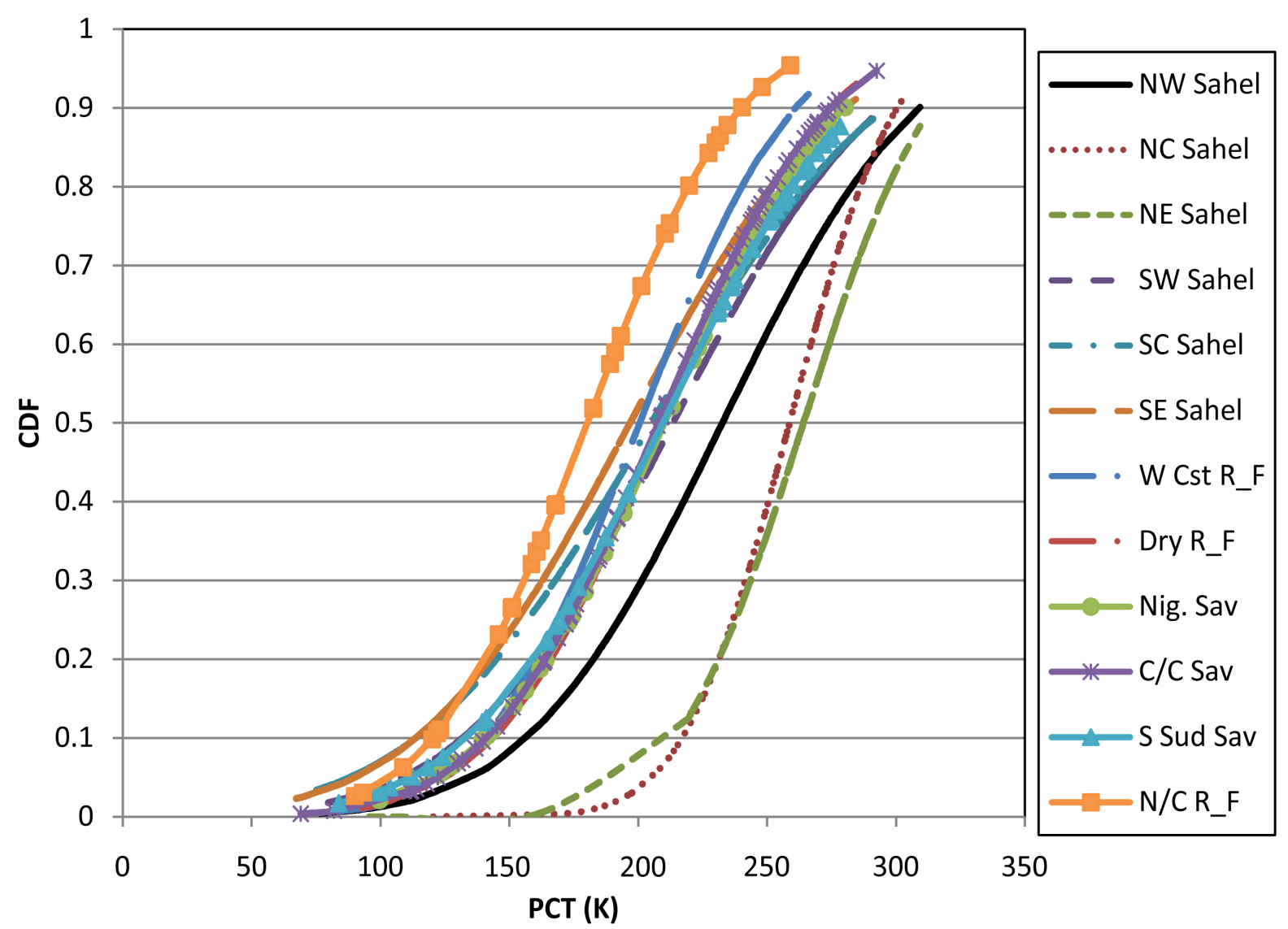

Figure 29. Convective intensity inferred from minimum $85-\mathrm{GHz}$ pct during SON.

light showers during JJA. The western-coast rainforest (topmost curve) is dominated with over $80 \%$ of $85-\mathrm{GHz}$ PCT values less than $250 \mathrm{~K}$, implying very deep convective system. It is not appropriate to classify these systems as an MCS since $85-\mathrm{GHz}$ PCT alone does not fully meets the MCS definition by [5]. Other parameters required for MCS is the near surface $20 \mathrm{dBZ}$ reflectivity (at least $20 \mathrm{dBZ}$ ) and the size or area ( $>2000$ $\mathrm{km}^{2}$ ).

During SON, as shown in Figure 29, all the regions have tendencies for lightning and thunderstorms activities. The AEJ, at this season, had its second appearance in the south whereas the northern Sahel regions are affected by the southward retreat of the ITD. Here, Nigeria/Cameroon rainforest (topmost curve) had about $95 \%$ of its $85-\mathrm{GHz}$ PCT less than $250 \mathrm{~K}$ and about $70 \%$ of the same parameter less than $200 \mathrm{~K}$. [20] indicated that $85-\mathrm{GHz}$ PCT with $225 \mathrm{~K}$ guarantees the presence of convective elements, and $225 \mathrm{~K}$ is selected in this study as the threshold for ice scattering of convective cores. [13] used criteria of the minimum $85-\mathrm{GHz}$ PCT $\leq 175 \mathrm{~K}$ for intense convection. Similarly, features with minimum $85-\mathrm{GHz}$ PCT $\leq 125$ or $100 \mathrm{~K}$ is interpreted as extremely intense convection [12]. Except for the three northern Sahel, all other regions have their median values less than $225 \mathrm{~K}$ for this season. Following [20] and Figure 8 and Figure 9 shown in previous section, there are indications of convective elements in the southern Sahel, savannah and rainforest while Nigeria/Cameroon rainforest with median value of at least $175 \mathrm{~K}$ indicated the presence of intense convection. 


\section{Conclusions}

Distribution of convective intensities have been analysed over the West Africa sub-region, considering twelve (12) zones in the region.

The ice scattering and radar reflectivity characteristics together provided information about the convective vigour of hydrometeors. From the results, we have seen some selected locations inside Western-coast rainforest, Nigeria/Cameroon rainforest and south Sudan savannah having strong potential for convective storms as indicated by their low $37-\mathrm{GHz}$ and $85-\mathrm{GHz}$ PCT values and the maximum height attained by their $30 \mathrm{dbz}$ and $40 \mathrm{dbz}$ reflectivities been above the freezing level.

The $85-\mathrm{GHz}$ PCTs were also used to determine the distribution of convective intensity across the twelve regions. It was observed that the percentage of convective intensity increases as the seasons and hence ITD advances north, during MAM and JJA, and retreat during SON.

\section{Acknowledgements}

The authors thank Chuntao Liu of the University of Utah (UU), now at Texas A \& M University Corpus Christi (TAMUCC) for his continued support of TRMM/PMM sciences and his contribution/Suggestion on one occasion on this work. All data used for this work were downloaded from the UU TRMM Database.

\section{References}

[1] Cecil, D.J. (2011) Relating Passive 37-GHz Scattering to Radar Profiles in Strong Convection. Journal of Applied Meteorology and Climatology, 50, 233-240. https://doi.org/10.1175/2010JAMC2506.1

[2] Liu, C., Cecil, D. and Zipser, E.J. (2011) Relationships between Lightning Flash Rates and Passive Microwave Brightness Temperatures at 85 and $37 \mathrm{GHz}$ over the Tropics and Subtropics. Journal of Geophysical Research, 116, D23108. https://doi.org/10.1029/2011JD016463

[3] Liu, C., Cecil, D.J., Zipser, E.J., Kronfeld, K. and Robertson, R. (2012) Relationships between Lightning Flash Rates and Radar Reflectivity Vertical Structure in Thunderstorms over the Tropics and Subtropics. Journal of Geophysical Research, 117, D06212.

https://doi.org/10.1029/2011JD017123

[4] Toracinta, E.R., Cecil, D.J., Zipser, E.J. and Nesbitt, S.W. (2002) Radar, Passive Microwave, and Lightning Characteristics of Precipitating Systems in the Tropics. Monthly Weather Review, 130, 802-824. https://doi.org/10.1175/1520-0493(2002)130<0802:RPMALC >2.0.CO;2

[5] Nesbitt, S.W., Zipser, E.J. and Cecil, D.J. (2000) A Census of Precipitation Features in the Tropics Using TRMM: Radar, Ice Scattering, and Lightning Observations. Journal of Climate, 13, 4087-4106. https://doi.org/10.1175/1520-0442(2000)013<4087:ACOPFI>2.0.CO;2

[6] Cecil D.J., Zipser, E.J. and Nesbitt, S.W. (2002) Reflectivity, Ice Scattering, and Lightning Characteristics of Hurricane Eyewalls and Rainbands. Part II: Intercomparison of Observations. Monthly Weather Review, 130, 785-801. https://doi.org/10.1175/1520-0493(2002)130<0785:RISALC>2.0.CO;2

[7] Wu, R. and Weinman, J.A. (1984) Microwave Radiances from Precipitating Clouds Containing Aspherical Ice, Combined Phase, and Liquid Hydrometeors. Journal of Geophysical Research, 89, 7170-7178. https://doi.org/10.1029/JD089iD05p07170

[8] Wilheit, T.T. (1986) Some Comments on Passive Microwave Measurement of Rain. Bulletin 
of the American Meteorological Society, 67, 1226-1232.

https://doi.org/10.1175/1520-0477(1986)067<1226:SCOPMM>2.0.CO;2

[9] Spencer, R.W. (1986) A Satellite Passive 37-GHz Scattering-Based Method for Measuring Oceanic Rain Rates. Journal of Applied Meteorology and Climatology, 25, 754-766. https://doi.org/10.1175/1520-0450(1986)025<0754:ASPGSB>2.0.CO;2

[10] Spencer, R.W., Goodman, H.G. and Hood, R.E. (1989) Precipitation Retrieval over Land and Ocean with the SSM/I: Identification and Characteristics of the Scattering Signal. Journal of Atmospheric and Oceanic Technology, 6, 254-273. https://doi.org/10.1175/1520-0426(1989)006<0254:PROLAO >2.0.CO;2

[11] Cecil D.J., Zipser, E.J. and Nesbitt, S.W. (2002) Reflectivity, Ice Scattering, and Lightning Characteristics of Hurricane Eyewalls and Rainbands. Part I: Quantitative Description. Monthly Weather Review, 130, 769-784. https://doi.org/10.1175/1520-0493(2002)130<0769:RISALC>2.0.CO;2

[12] Xu, W., Zipser, E.J., Liu, C. and Jiang, H. (2010) On the Relationships between Lightning Frequency and Thundercloud Parameters of Regional Precipitation Systems. Journal of Geophysical Research, 115, D12203. https://doi.org/10.1029/2009JD013385

[13] Mohr, K.I. and Zipser, E.J. (1996) Mesoscale Convective Systems Defined by Their 85-GHz Ice Scattering Signature: Size and Intensity Comparison over Tropical Oceans and Continents. Monthly Weather Review, 124, 2417-2437. https://doi.org/10.1175/1520-0493(1996)124<2417:MCSDBT>2.0.CO;2

[14] Mohr, K.I., Famiglietti, J.S. and Zipser, E.J. (1999) The Contribution to Tropical Rainfall with Respect to Convective System Type, Size, and Intensity Estimated from the $85-\mathrm{GHz}$ Ice-Scattering Signature. Journal of Applied Meteorology, 38, 596-606. https://doi.org/10.1175/1520-0450(1999)038<0596:TCTTRW >2.0.CO;2

[15] Cecil, D.J. and Zipser, E.J. (1999) Relationships between Tropical Cyclone Intensity and Satellite-Based Indicators of Inner Core Convection: $85 \mathrm{GHz}$ Ice-Scattering Signature and Lightning. Monthly Weather Review, 127, 103-123.

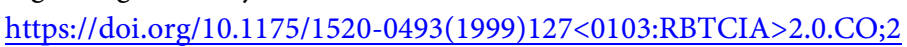

[16] DeMott, C.A. and Rutledge, S.A. (1998) The Vertical Structure of TOGA COARE Convection. Part I: Radar Echo Distributions. Journal of the Atmospheric Sciences, 55, 2730-2747. https://doi.org/10.1175/1520-0469(1998)055<2730:TVSOTC>2.0.CO;2

[17] Zipser, E.J., Cecil, D., Liu, C., Nesbitt, S. and Yorty, D. (2006) Where Are the Most Intense Thunderstorms on Earth? Bulletin of the American Meteorological Society, 87, 1057-1071. https://doi.org/10.1175/BAMS-87-8-1057

[18] Cecil, D.J., Goodman, S.J., Boccippio, D.J., Zipser, E.J. and Nesbitt, S.W. (2005) Three Years of TRMM Precipitation Features. Part I: Radar, Radiometric, and Lightning Characteristics. Monthly Weather Review, 133, 543-566. https://doi.org/10.1175/MWR-2876.1

[19] Vivekanandan, J., Turk, J. and Bringi, V.N. (1991) Ice Water Path Estimation and Characterization Using Passive Microwave Radiometry. Journal of Applied Meteorology, 30, 14071421. https://doi.org/10.1175/1520-0450(1991)030<1407:IWPEAC>2.0.CO;2

[20] McGaughey, G.R., Zipser, E.J., Spencer, R.W. and Hood, R.E. (1996) High-Resolution Passive Microwave Observations of Convective Systems over the Tropical Pacific Ocean. Journal of Applied Meteorology, 35, 1921-1947. 
Submit or recommend next manuscript to SCIRP and we will provide best service for you:

Accepting pre-submission inquiries through Email, Facebook, LinkedIn, Twitter, etc. A wide selection of journals (inclusive of 9 subjects, more than 200 journals) Providing 24-hour high-quality service

User-friendly online submission system

Fair and swift peer-review system

Efficient typesetting and proofreading procedure

Display of the result of downloads and visits, as well as the number of cited articles Maximum dissemination of your research work

Submit your manuscript at: http://papersubmission.scirp.org/

Or contact acs@scirp.org 